\title{
Control of Calix[6]arene Conformations by Self-Inclusion of 1,3,5-Tri-O-alkyl Substituents: Synthesis and NMR Studies ${ }^{\dagger}$
}

\author{
John P. M. van Duynhoven, $¥$ Rob G. Janssen,' Willem Verboom,' Sybille M. Franken, \\ Alessandro Casnati, $\perp$ Andrea Pochini, $\perp$ Rocco Ungaro, $\perp$ Javier de Mendoza,' \\ Pedro M. Nieto," Pilar Prados," and David N. Reinhoudt",
}

Contribution from the Laboratory of Organic Chemistry, Laboratory of Chemical Analysis, and Laboratory of Chemical Physics, University of Twente, P.O. Box 217, 7500 AE Enschede, The Netherlands, Dipartimento di Chimica Organica e Industriale dell' Universitz. Viale delle Scienze, 43100 Parma, Italy, and Department de Quimica Organica, Universidad Autonbma de Madrid, 28049 Madrid, Spain

Recetved December 8, $1993^{\circ}$

\begin{abstract}
Hexa-0-alkylated p-tert-butylcalix[6]arenes with an alternate $1,3,5-R_{1}-2,4,6-R_{2}$-substitution pattern have been prepared and studied by. NMR spectroscopy. When $R_{1}=C_{3}$ and $R_{2}$ is a bulky substituent, the calix[6]arene moiety adopts predominantly a flattened cone conformation. At room temperature this conformation slowly interconverts with a 1,2,3-alternate conformation $\left(\Delta G^{*}=70-88 \mathrm{~kJ} \mathrm{~mol}^{-1}, T=328 \mathrm{~K}, \mathrm{CDCl}_{3}\right)$. The Gibbs free energy between these two conformations at $T=303 \mathrm{~K}$ in $\mathrm{CDCl}_{3}$ varies from 2 to $7 \mathrm{~kJ} \mathrm{~mol}^{-1}$. From quantitat $\mathrm{Ne}$ NOE data (obtained for 1,3,5-trimethoxy-2,4,6-tris[(3-nitrobenzyl)oxy]-p-tert-butylcalix[6]arene (10) three-dimensional structures of the flattened cone and the 1,2,3-alternate conformers were calculated. In both conformers the methoxy groups are accommodated in the annulus of the calix [6]arene skeleton, indicating specific interactions with the aromatic calixarene moiety. Compared to the hexasubstituted analogues, this structural feature slightly increases the activation Gibbs free energy for the interconversion process (13-21 kJ mol-1). Even with substituents that are too large to rotate through the annulus, there is still slow interconversion $\left(\Delta G^{*}=88 \mathrm{~kJ} \mathrm{~mol}^{-1}, T=328 \mathrm{~K}, \mathrm{CDCl}_{3}\right)$. This is attributed to a very slow transannular motion of the p-tert-butyl moiety. Also the ethoxy (16) or propoxy (17) derivatives of 2,4,6-tris( $N, N$-diethylacetamido)-p-tert-butylcalix [6]arene predominantly adopt flattenod cone (16) and 1,2,3-alternate (17) conformations, respectively. The self-inclusion of the larger alkyl groups also contributes to the overall conformational freezing of the p-tert-butylcalix[6]arenes.
\end{abstract}

\section{Introduction}

Calix[4]arenes 1,2 have proven to be a very useful threedimensional molecular building block for the synthesis of molecules with specific properties. ${ }^{3}$ The calix[4]arene moiety can exist in four different (up, down) conformations, which can be fixed by introduction of four bulky substituents ( $R>$ ethyl) at the lower rim.4 General methods have been developed for the selective synthesis of $O$-alkylated calix[4]arenes ${ }^{5}$ in the cone, ${ }^{2,6}$

Tresented in part at the XVIII International Symposium on Macrocyclic Chemistry, Enschede, The Netherlands, June 27-July 2, 1993, Abotract Book p A-95.

Laboratory of Chemical Analysis, University of Twente.

I Laboratory of Organic Chemistry, University of Twente.

Laboratory of Chemical Physics, University of Twente.

$\perp$ Istituto di Chimica Organica dell' Universita, Parma.

* Universidad Autonoma de Madrid.

- Universidad Autonoma de Madrid.

(1) The substructure consisting of the phenolic oxygens is calied the lower rim, while that of the para positions is called the upper rim of a calixarene. 2) Gutsche, C. D. Callxarenes, Monographs in Supramolecular Chemistry Stoddard, J. F.; Ed.; Royal Society of Chemistry: Cambridge, U.K. 1989 Vol. 1. Callxarenes, A Versallle Class of Macrocyclic Compounds Vicens, J., Borhmer, V., Eds.; Kluwer Academic Publishers: Dordrecht, The Netharlands, 1991 .

(3) For a few recent applications, see: (a) Arnaud-Neu, F; Collins, E. M Deasy, M.; Ferguson, O.; Harris, S. J.; Kaitner, B.; Lough, A. J.; MeKervoy, M. A., Marques, E.; Rubl, B. L.i Schwing-Weill, M. J.; Seward, E. M. J. Am. Chem. Soc. 1989, III, 8681-8691. (b) Dijkstra, P, J.; Brunink, J. A. J Bugge, $K_{1}-E_{\text {; }}$ Reinhoudt, $\mathrm{P}$. N.; Harkema, S.; Ungaro, R.; Ugozzoli, F. Ghidini, E.J.Am. Chem.Soc. 1989, 111,7567-7575. (c) Ghidini, E.; Ugozzol, F.; Ungaro, R.; Harkema, S.; El-Fadl, A. A.; Reinboudt, D. N. J. Am. Chem Soc. 1990, 112, 6979-6985. (d) Cobben, P. H. L. M.; Egberink, R. J. M. Bomer, J. G.; Bergveld, P.; Verboom, W.; Reinhoudt, D, N. J. Am. Chem Soc. 1992, 114, 10573-10582. (e) Kelderman, E.; Derhaeg, L.; Hoesink, O. J. T.; Verboom, W.; Engbersen, J. F. J, van Hulst, N. F.; Persoons, A. Reinhoudt, D. N. Angew. Chem. Int. Ed. Engl. 1992, 31, 1075-1077.

(4) Iwamoto, K.; Araki, K.; Shinkai, S. J. Org. Chem. 1991, 56, 4955-

(5) Iwamoto, K,; Araki, K,; Shinkai, S. Tetrahedron 1991, 17, 4325-4342. partial cone, ${ }^{7}$ and 1,3-alternate conformation, ${ }^{8}$ The parent calix[4]arene and calix [4]arenes with methoxy or ethoxy groups at the lower rim are conformationally mobile, because these groups can rotate through the calixarene annulus. 9 We have elucidated the mechanism of the conformational interconversions in quan titative terms by 2D EXSY NMR spectroscopy.9,10

The conformations of calix [6]arenes have hardly been studied, mainly because of their higher degree of functionality and conformational flexibility, although the synthesis and properties of different hexafunctionalized calix [6] arenes have been described by several groups, ${ }^{3 a, 74,11-13}$ Recently the selective aroylation, ${ }^{14}$ arylmethylation, ${ }^{15}$ methylation, ${ }^{16}$ (thio)phosphorylation, ${ }^{17}$ py.

(6) Groenen, L. C.; Ruêl, B. H. M.; Casnati, A.; Timmerman, P.; Verboom W. Harkema, S.; Pochini, A.; Ungaro, R.; Reinhoudt, D. N. Tetrahedron Cett. 1991, 32, 2675-2678.

(7) (a) Gutgche, C. D.; Reddy, P. A. J. Org. Chem. 1991, 56, 4783-4791 (b) Iwamoto, K.; Araki, K.; Shinkai, S. J. Org. Chem. 1991, 56, 4955-4962 (8) Verboom, W.; Datta, S.; Asfari, Z.; Harkema, S.; Reinhoudt, D. N. J. Org. Chem. 1992, 57, 5394-5398.

(9) Groenen, L. C.; van Loon, J.-D.; Vorboom, W.; Harkema, S,; Casnati, A.; Ungaro, R.; Pochini, A.; Ugozzoli, F.; Reinhoudt, D. N. J. Am. Chem. Soc, $1991,113,2383-2392$.

(10) van Loon, J.-D.i Groonen, L. C.; Wijmenga, S. S.; Verboom, W. Reinhoudt, D. N, J. Am. Chem. Soc. 1991, II3, 2378-2384.

(11) (a) Shinkai, S.; Mori, $S_{\text {.i }}$ Tsubaki, $T$.; Sone, T,; Manabe, 0 Tetrahedron Lett. 1984, 46, 5315-5318. (b) Shinkal, S.; Shiramama, $Y$. Satoh, H.; Manabe, O.; Arimura, T.; Fujimoto, K.i Matsuda, T, J. Chem Sac, Perkin Trans, $21989,1167-1171$, (c) Nagasald, T, Arimura, T.; Shinkai . Bull. Chem. Soc. Jpn. 1991, 61, 2575-2577.

(12) Chang, S.-K,; Cho, J. J. Chem. Soc., Perkin Trans. 1 1986, 211-214, (13) Ungaro, R.; Pochini, A.; Andreettl, G. D.; Domiano, P. J. Inclusion Phenom. 1987, $5,123-126$.

14) Rogers, J. S.; Outsche, C. D. J. Org. Chem. 1992, 57, 3152-3159. 3166.

(16) Jansen, R. O.; Verboom, W.; Reinhoudt, D. N.; Casnati, A.; Freriks, M.; Pochini, A.; Ugozzoll, F.; Ungaro, R.; Nioto, P. M.; Carramolino, M. Cuevas, F,; Prados, P.; de Mendoza, J. Synthesis 1993, 380-386. 
ridylmethylation, 18 bridging, 19 and upper rim functionalization 20 of $p$-tert-butylcalix[6]arenes have been reported.

Previous work has shown that in hexa-Oalkylated calix [6]arenes it is difficult to block the conformational interconversion by attachment of bulky groups at the lower rim.21 A systematic study of structure-conformation relations by Gutsche et al. ${ }^{14,15}$ showed that 1,2,4,5-tetrakis(arylmethylated) or-aroylated p-tertbutylcalix [6]arenes adopt 1,2,3-alternate conformations, ${ }^{22}$ while in the corresponding 1,4-bis-substituted derivatives the substituents are 'syn' oriented. Pappalardo et al. ${ }^{18 b}$ showed by dynamic NMR techniques that the 1,2,4,5-alternate conformation of 1,2,4,5-tetrakis [(2-pyridylmethyl)oxy]-p-tert-butylcalix[6]arene changes from a $C_{2}$ symmetry at low temperature to a statistical $D_{2}$ symmetry upon heating. The same was observed by Molins et al. ${ }^{23}$ for a calix[6]arene which is alternately substituted with tert-butyl groups and chloro substituents at the upper rim. The conformation becomes statistically $C_{30}$-symmetric at ambient temperature, while at low temperature the conforma. tion is frozen into a nonsymmetric winged cone conformation.

The objective of the work described in this paper is to control the conformation of calix[6]arenes and to design specifically substituted calix[6]arenes with frozen conformations. ${ }^{24}$ Recently we reported that ${ }^{25} 1,3,5$-trimethoxy-2,4,6-tris $(N, N$-diethylacetamido)-p-tert-butylcalix [6] arene ${ }^{26}$ is present in $\mathrm{CHCl}_{3}$ solution as a flattened cone conformer, although the corresponding hexamide is mobile. ${ }^{27}$ In order to investigate the influence of lower rim alkyl substituents on the conformations and the energy barrier for interconversion, we have prepared a series of $1,3,5$ trialkoxy-2,4,6-trisubstituted calix [6]arenes. In this paper we present the first quantitative data on the conformational interconversion of a series of fully alkylated calix[6]arenes. These indicate that a weak intramolecular force resulting from the selfinclusion of small alkyl groups may contribute to control the relative energies of specific conformers.

\section{Results and Discussion}

Synthesis. All calix [6]arene deriyatives were synthesized from 1,3,5-trimethoxy-p-tert-butylcalix [6] arene (1). ${ }^{16}$ Reaction of 1 (Chart 1) with excess of acetyl chloride in the presence of thallium(I) ethoxide as a base in $\mathrm{Et}_{2} \mathrm{O}$ gave the acetylated derivative 2 in $86 \%$ yield. The calix [6]arenes 4,5 , and 7-9 were prepared in $70-80 \%$ yield by reaction of 1 with excess alkylating agent and $\mathrm{NaH}$ as a base in refluxing THF. Reaction of 1 with 6 equiv of the appropriately substituted benzyl bromide in the presence of

(17) Janssen, R. G.; Verboom, W.; Harkema, S,; van Hummel, G, J, Reinhoudt, D. N.; Pochini, A.; Ungaro, R.; Prados, P.; de Mendoza, $j$. $j$. Reinhoudt, D. N.; Pochini, A.; Ungaro, R,; Prad
Chem. Soc., Chem. Commun. 1993, 506-508.

(18) (a) Pappalardo, S. J. Org. Chem. 1993, 58, 1048-1053, (b) Neri, P, Foti, M.; Ferguson, G.; Gallagher, J. F; Kaitner, B.; Pons, M.; Molins, M. A.i Giunta, L; Pappalardo, S. J. Am. Chem. Soc. 1992, $114,7814-7821$. (c) Shinkal, S.; Fujimoto, K.; Otsuka, T.; Ammon, H. L. J. Org. Chem. 1992, 57, 1516-1523.

(19) Kanamathareddy, S.; Gutscbe, C. D. J. Am. Chem. Soc. 1993, 115, $6572-6579$.

(20) de Mendoza, J.; Carramolino, M.; Cuevaa, F.; Nieto, P. M.; Prados, P.i Reinhoudt, D. N.; Verboom, W.; Ungaro, R.; Casnati, A. Symthesis 1994,
47-50

(21) Gutsche, C. D.; Bauer, L. J. J. Am. Chem. Soc, 1985, 107, 60596063.

(22) Ikeda, A.; Nagasakl, T,; Shinkai, S. J. Phys, Org. Chem. 1992, S. $699-710$.

(23) Molins, M. A.; Nieto, P. M.; Sánchez, C.; Prados, P.; de Mendoza, J.; Pons, M. J. Org. Chem. 1992, 57, 6924-6931.

(24) We define the freezing of conformations a the situation in which activation barriers betwoen multiple conformers are high enough to result in interconversion rates of less than $0.05 \mathrm{~s}^{-1}$ at $298 \mathrm{~K}$. When conformation are fixed, interconversion rates have dropped to such an extent that phyaical separation of stable conformers is in principle possible.

(25) Casnati, A.; Minari, P,; Pochini, A,; Ungaro, R. J. Chem. Soc., Chem. Commun. 1991, $1413-1414$.

(26) The phenolic hydroxyl groups, which are attached to carbon atoms $37-42$ are numbered from $1-6$ to glve a better insight in the substitution $37-42$ are numbered from $1-6$ to give a
pattern of functionalized calix[6]arenes.

(27) Casnati, A.; Minari, P.; Pochini, A.; Ungaro, R.; Nijenhuis, W. F.; de Jong, F.; Reinhoudt, D. N. Isr. J. Chem. 1992, 32, 79-87.
Chart 1
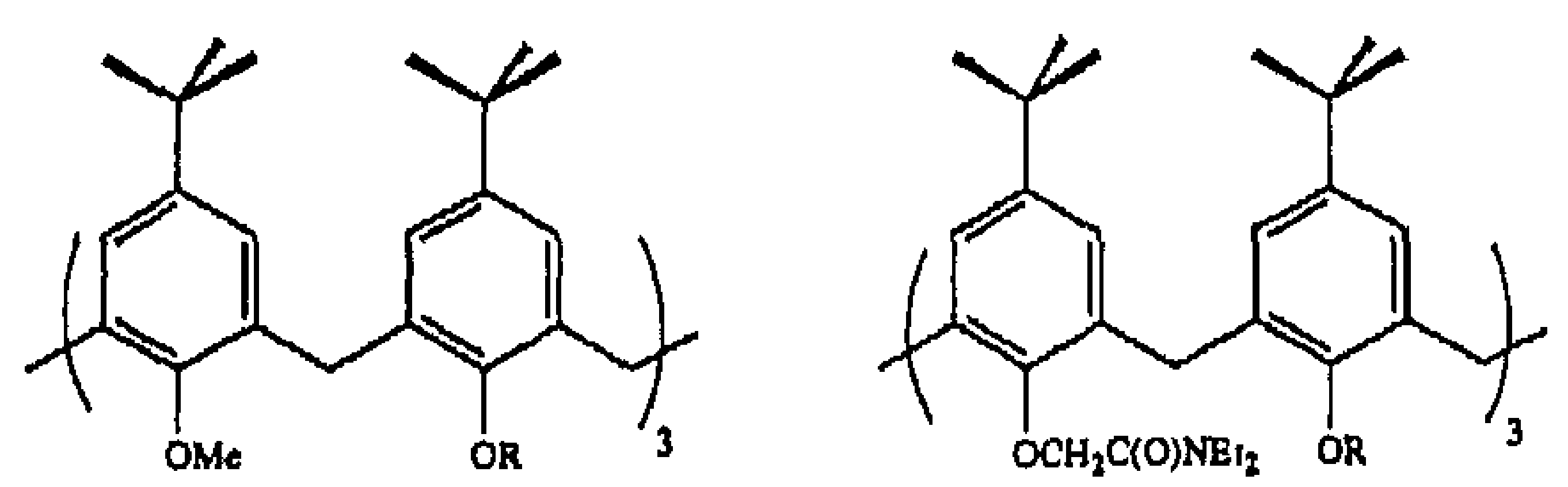

$$
\begin{aligned}
& R=\mathbf{H} \\
& R=A c \\
& \mathrm{R}=\mathrm{CH}_{2} \mathrm{C}(\mathrm{O}) \mathrm{NEt}_{2} \\
& \mathrm{R}=\mathrm{CH}_{2} \mathrm{C}_{\mathrm{H}} \mathrm{H}_{3} \\
& \mathrm{R}=\mathrm{CH}_{2} \mathrm{C}(\mathrm{O}) \mathrm{O}-\mathrm{-}-\mathrm{C}_{4} \mathrm{H}_{9} \\
& \mathrm{R}=\mathrm{CH}_{2} \mathrm{COOH} \\
& \mathrm{R}=\mathrm{CH}_{2} \mathrm{CH}=\mathrm{CH}_{2} \\
& \mathrm{R}-\mathrm{CH}_{2} \mathrm{C}=\mathrm{CH} \\
& \mathrm{R}=\mathrm{CH}_{2}-\left(4-\mathrm{Br}^{-}-\mathrm{C}_{6} \mathrm{H}_{4}\right) \\
& \mathrm{R}=\mathrm{CH}_{2}-\left(3-\mathrm{NO}_{2} \cdot \mathrm{C}_{6} \mathrm{H}_{4}\right) \\
& \mathrm{R}=\mathrm{CH}_{2}-\left(3-\mathrm{CN} \cdot \mathrm{C}_{4} \mathrm{H}_{4}\right) \\
& R=P(O) \text { (OEI) } \\
& \mathrm{R}=\mathrm{CH}_{2}-(2-\mathrm{nuphthyl)} \\
& \mathrm{R}=\mathrm{CH}_{2}-\left(4-\mathrm{C}_{8} \mathrm{H}_{4} \cdot \mathrm{C}_{2} \mathrm{H}_{4}\right)
\end{aligned}
$$$$
15 \quad R=H
$$$$
16 \quad \mathrm{RaBt}
$$$$
17 \quad R=P \text { T }
$$

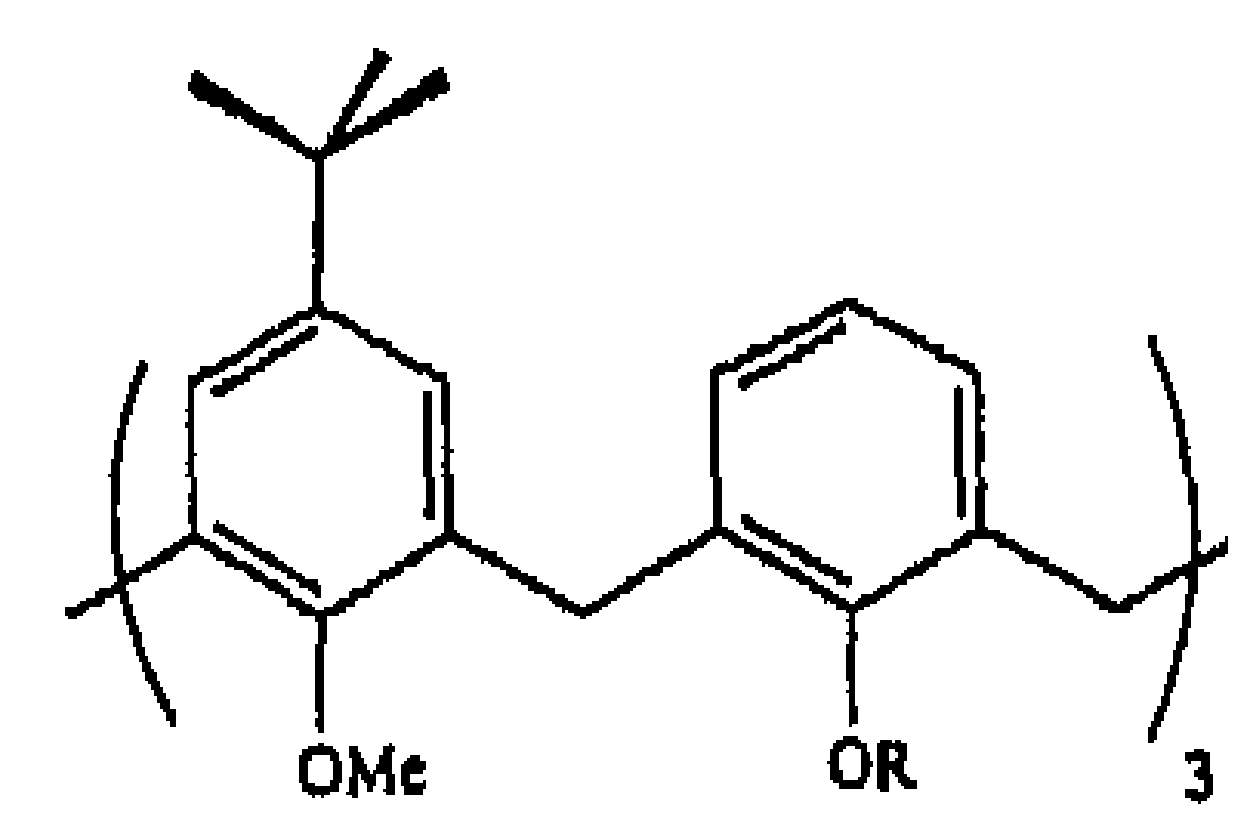

$18 \mathrm{R} \times \mathrm{H}$

$19 \quad \mathrm{R}=\mathrm{CH}_{2}-\left(3 \cdot \mathrm{NO}_{2}-\mathrm{C}_{1} \mathrm{H}_{4}\right)$

6 equiv of $\mathrm{C}_{2} \mathrm{CO}_{3}$ as a base in DMF at $70-80^{\circ} \mathrm{C}$ afforded 10 and 11 in yields of 93 and $96 \%$, respectively. In a similar way compounds 13 and 14 were synthesized in yields of 77 and $89 \%$, respectively. Phosphorylation of 1 with an excess of diethoxy phosphoryl chloride and $50 \%$ aqueous $\mathrm{NaOH}$ under phase-transfer conditions in $\mathrm{CH}_{2} \mathrm{Cl}_{2}$ gave the triphosphate 12 in $36 \%$ yield. Hydrolysis of the tert-butyl ester 5 with trifluoroacetic acid at room temperature afforded the corresponding triacid 6 in $85 \%$ yield.

For our NMR studies (vide infra) we also needed the 1,3,5triethoxy- (16) and 1,3,5-tripropoxy-2,4,6-triamide (17). Since, 1,3,5-trialkylation of $p$-tert-butylcalix [6]arene seems to be limited to methylation, ${ }^{16}$ compounds 15-17 were prepared using an indirect method. Demethylation of the sodium complex of 3 with 6 equiv of trimethylsilyl iodide in refluxing $\mathrm{CHCl}_{3}$ gave 15 in $83 \%$ yield. ${ }^{28}$ Ethylation of 15 with ethyl iodide and $\mathrm{NaH}$ as a base in refluxing THF gave 16 in $58 \%$ yield, and propylation using 6 equiv of $\mathrm{Cs}_{2} \mathrm{CO}_{3}$ in DMF at $70^{\circ} \mathrm{C}$ gave 17 in $95 \%$ yield. In order to study the influence of the p-tert-butyl substituent on the relative stability of the different conformers, 1 was selectively de-tert-butylated, using the profound difference in reactivity between a phenol and an anisole ring, ${ }^{29}$ with 9 equiv of freshly sublimed $\mathrm{AlCl}_{3}$ in dry toluene to give 18 in $81 \%$ yield. Subsequent alkylation of 18 with 6 equiv of 3-nitrobenzyl bromide and $\mathrm{Cs}_{2}$ $\mathrm{CO}_{3}$ as a base gave 19 in $80 \%$ yield.

Variable-Temperature NMR Studies of 1,3,5-Trimethoxycallx[6]arenes 2-14. The 'H NMR spectra of 1,3,5-trimethoxysubstituted compounds have been recorded at different temperatures in both $\mathrm{CD}_{2} \mathrm{Cl}_{2}(193-313 \mathrm{~K})$ and $\mathrm{CDCl}_{3}(213-353 \mathrm{~K})$. The 'H NMR spectrum at low temperature of 2 shows multiple broadened lines, which coalesce at elevated temperature (Figure 1A). At temperatures $>323 \mathrm{~K}$ the spectrum is well resolved with two pairs of singlets for the aromatic and the p-tert-butyl protons and singlets for the methoxy and acetoxy as well as the bridging $\mathrm{CH}_{2}$ protons. This indicates that all rings rotate through the annulus at rates that expose both bridging methylene protons to the same time-averaged magnetic environment (Table 1).

Compounds $6-8$ behave similarly, with methylene resonances coalescing between 313 and $333 \mathrm{~K}$. The $1 \mathrm{H}$ NMR spectra of 3

(28) It is essential to use the sodium complex of 3 in order to prevent the ceavage of other other bonds.

(29) van Loon, J.-D.; Arduini, A.; Coppi, L.; Verboom, W.; Pochini, Ari Ungaro, R.; Harkema, S.; Reinhoud, D. N. J. Org. Chem. 1990, 55, 56395646 . 


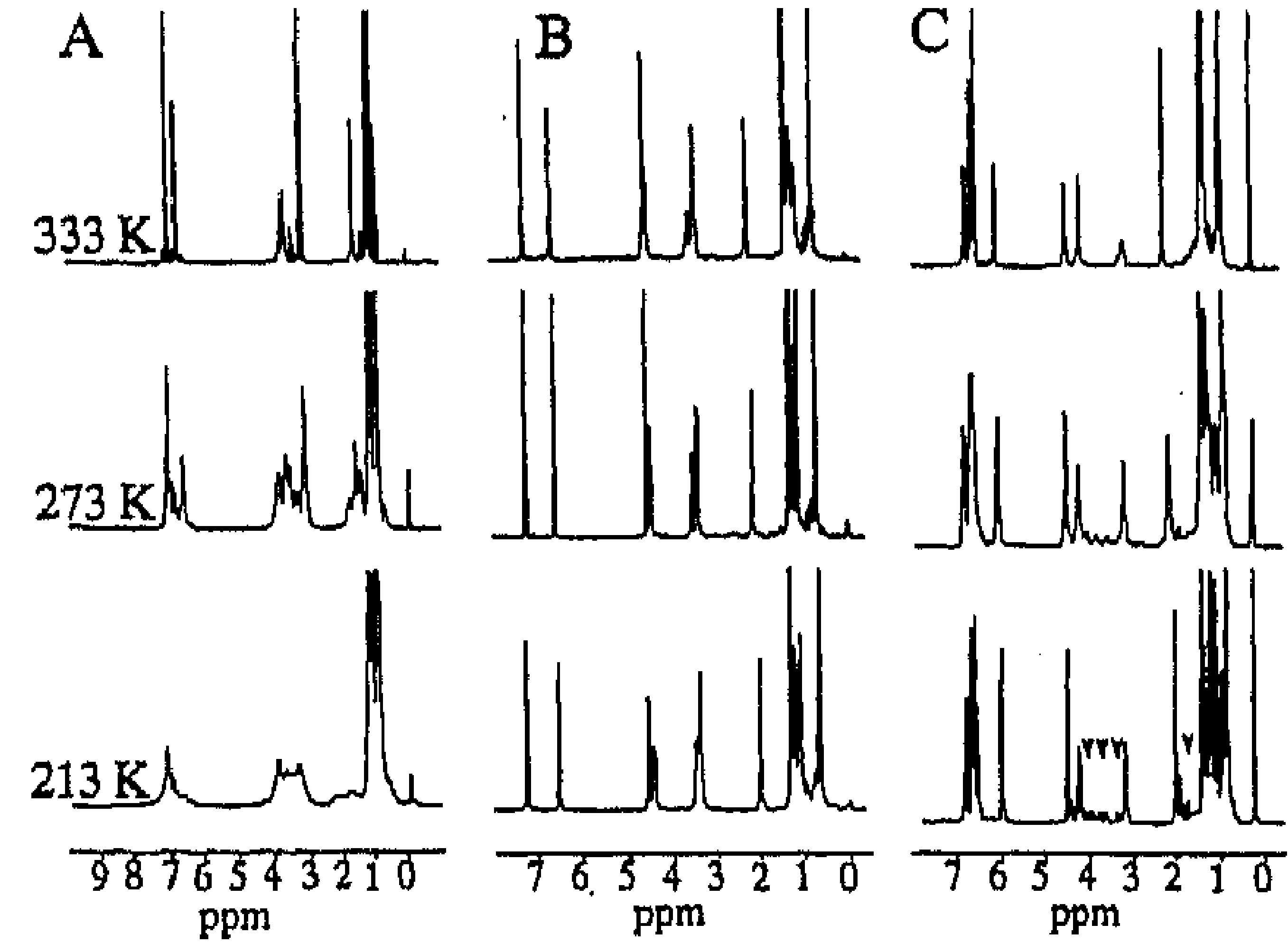

Figure 1. 'H NMR spectra of compounds 2 (A), 3(B), and 4 (C) recorded at 213,273 , and $333 \mathrm{~K}$ in $\mathrm{CDCl}_{3}$. The arrows indicate minor $\left(C_{t}\right.$ symmetry) signals (see text).

Table 1. Symmetry Dependence of 'H NMR Spectral Features of 1,3,5-Trimethoxy-2,4,6-trisubstituted p-tert-Butylcalix [6]arenes"

\begin{tabular}{lllll}
\hline group & \multicolumn{1}{c}{ flexible } & \multicolumn{1}{c}{$C_{30}$} & \multicolumn{1}{c}{$C_{s}$} & nonsymmetric \\
\hline tert-butyl & $2 \mathrm{~s}(2 \mathrm{H})$ & $2 \mathrm{~s}(27 \mathrm{H})$ & $2 \mathrm{~s}(18 \mathrm{H}), 2 \mathrm{~s}(9 \mathrm{H})$ & $6 \mathrm{~s}(9 \mathrm{H})$ \\
$\mathrm{OCH}_{3}$ & $\mathrm{~s}(9 \mathrm{H})$ & $\mathrm{s}(9 \mathrm{H})$ & $\mathrm{s}(6 \mathrm{H}), \mathrm{s}(3 \mathrm{H})$ & $3 \mathrm{~s}(3 \mathrm{H})$ \\
$\mathrm{CH}_{2}$ & $\mathrm{~s}(12 \mathrm{H})$ & $2 \mathrm{~d}(6 \mathrm{H})^{b}$ & $6 \mathrm{~d}(2 \mathrm{H})^{b}$ & $12 \mathrm{~d}(1 \mathrm{H})^{b}$ \\
$\mathrm{Ar}^{b}$ & $2 \mathrm{~s}(6 \mathrm{H})$ & $2 \mathrm{~s}(6 \mathrm{H})$ & $2 \mathrm{~s}(2 \mathrm{H}), 4 \mathrm{~d}(2 \mathrm{H})^{c}$ & $12 \mathrm{~d}(1 \mathrm{H})^{c}$ \\
\hline
\end{tabular}

a Denoted are the number of degenerate singlets (s) and doublets (d). The number of hydrogen atoms are placed in parentheses. ${ }^{b} \approx 16 \mathrm{~Hz}$. $C J \approx 2 \mathrm{~Hz}$

(Figure 1B) show completely different characteristics. At low temperatures, due to internal hindered rotation around the $\mathrm{C}-\mathrm{N}$ bond, the acetamido substituent gives two $A_{2} X_{3}$ spin systems, which coalesce at $323 \mathrm{~K}$, but most of the ${ }^{1} \mathrm{H}$ NMR lines remain virtually unchanged over the range of the temperature series. The same behavior was also observed for compounds 5 and 9-14. Compound 4 shares the characteristics of these compounds, but over a smaller temperature range (Figure 1C). In the spectra of the compounds 3-5 and 9-14, the methylene protons appear as two separate resonances (AB system), which points to no or slow interconversion of the aromatic rings. For both the aromatic and tert-butyl protons two signals are present from the $\mathrm{E}$ and $\mathrm{O}$ moieties, ${ }^{30}$ respectively, indicating a conformation with $C_{30}$ symmetry. In these spectra in addition signals of low intensity are present close to the intense signals of the $C_{3 v}$ conformer. These were assigned to a second conformer (vide infra). Compound 4 exhibits exchange broadening of these resonances at ambient temperatures, clearly indicating fast conformational interconversion between these two conformers. The other compounds do not show exchange broadening, but a dynamic equilibrium with another conformer follows from the exchange connectivities in NOESY / ROESY experiments recorded above room temperature (vide infra). The p-tert-butyl and methoxy signals of compounds 3-5 and 9-14 are each in slow chemical exchange with spin systems consisting of two singlets with the intensity ratio $2: 1$. Combination of exchange connectivities with DQF-COSY data shows that the (major) bridging methylene AX spin system is interconverting with three other (minor) AX spin systems. The multiplicity and intensity ratios of these and other signals are in accordance with a $C_{\text {, symmetry (Table 1) for }}$ this minor conformer. Compared with the hexasubstituted analogues, which are much more flexible (vide supra), the kinetic stability of the $C_{30}$ conformer of 3-5 and 9-14 is striking. In order to study the nature of this effect, we have first determined

(30) The $O$ (odd) rings are the aromatic moieties, substitutod with methoxy groups, while the $E$ (even) rings are substituted with other than methoxy groups. the structure of the $C_{30}$ and $C_{8}$ conformers and elucidated the interconversion process in quantitative terms.

IH NMR Assignments of the Aromatic and p-tert-Butyl Resonances of Callix [6]arenes 3-5 and 9-14. Elucidation of both the $C_{30}$ and $C_{3}$ conformers involved the extraction of throughspace connectivities from NOESY and/or ROESY spectra. A prerequisite for this procedure is the 'H NMR assignment of the p-tert-butyl and aromatic proton resonances in a substituentspecific manner. This requires the establishment of a throughbond connectivity between the resonances of the lower rim substituents and the aromatic and p-tert-butyl protons. We applied the procedure outlined previously, ${ }^{23}$ which involves the partial assignment of the ${ }^{13} \mathrm{C}$ NMR spectrum using $H M Q C$ and HMBC experiments. The definitive ${ }^{1} \mathrm{H}$ NMR resonance assignments of the $C_{30}$ conformers of 3-5 and 9-14, together with the chemical shift positions of the $C$, conformer signals, are shown in Tables 2 and 3, respectively. Their assignment was carried out in a straightforward manner by scrutiny of the exchange connectivities between the $C_{s}$ conformer signals and the already assigned $C_{3 v}$ conformer signals.

Spatial Structure Elucidation of the $C_{3}$, and $C_{3}$ Conformers. All experiments aimed to get qualitative distance information concerning $C_{30}$ and $C_{1}$ conformers were performed at temperatures where their interconversion rate has decreased to such an extent that no observable exchange crosspeaks were discernible in the NOESY (or ROESY) spectra. Under these conditions we can assume that there is no buildup of any transferted NOE. ${ }^{31}$ Only calix[6]arene 4 had to be cooled to $233 \mathrm{~K}$ to obtain sufficient conformational freezing; for the other compounds this condition is already fulfilled at ambient temperature. However, at this temperature, the tumbling rate of calix [6]arenes is in the regime that the NOE effect changes sign at $400 \mathrm{MHz}$. For this reason ROESY experiments were performed to obtain (qualitative) through-space connectivities of sufficient intensity. The ROESY data for compounds 3-5 and 9-14 gave the same through-space connectivity pattern for all $C_{30}$ spin systems (Figure $2 \mathrm{~A}$ ).

The strong ROE contacts between the aromatic protons of $O$ and $E$ rings exclude any alternate or anti conformation, leaving a cone-like structure as the only possibility. The ROEs between the axial methylene bridge and aromatic protons of the $O$ and $E$ rings differ significantly in intensity, and this corresponds to an "out" conformation of the anisole moieties. Weak contacts between the methoxy groups and the aromatic protons of the $E$ rings in combination with the strong upfield shift of the methoxy resonances are indicative of the inclusion of these groups in the calix[6]arene annulus. Using Gutsche's nomenclature, ${ }^{19}$ we designate this conformation as $(u, u o, u, u o, u, u o)$.

Analysis of the ROE data of the $C_{t}$ conformer signals gives the connectivity pattern depicted in Figure $2 \mathrm{~B}$. Contacts between the aromatic protons of rings $O_{1}, E_{2}, O_{1}, E_{6}$ and $O_{3}, E_{4}, O_{5}, E_{4}$ clearly indicate that these rings are syn or 'syn-like' relative to each other. The pattern of ROE contacts between rings $\mathrm{E}_{2}, \mathrm{O}_{3}$ and $\mathrm{E}_{6}, \mathrm{O}_{5}$ is typical of an anti conformation. Therefore we conclude that the $C_{s}$ conformer adopts a 1,2,3-alternate conformation. The resonances of the methoxy groups appear at upfield chemical shift and show through-space contacts to aromatic ring protons. This indicates that also in the 1,2,3-alternate conformation the methoxy groups point toward the aryl groups of the calix[6]arene cavity. In order to obtain more quantitative information about the distances in both conformers, spectroscopy at a field strength of $600 \mathrm{MHz}$ was necessary, because then NOESY renders NOE crosspeaks of considerable positive intensity at $273 \mathrm{~K} .32 \mathrm{At}$

(31) A transferred NOE is an NOE transferred between conformers by chemical exchange.

(32) The main advantage of NOEs over ROEs is that they can be translated into quantitative ' $\mathrm{H}-1 \mathrm{H}$ distance information in a rather straightforward manner, whereas the calculation of distances from ROESY data requires extensive frequency offset corrections. 
Table 2. Selected 'H NMR Data of the Flattened Cone $\left(C_{3 a}\right)$ Conformers of 1,3,5-Trimethoxy-2,4,6-trisubstituted p-tert-Butylcalix[6]arenes in $\mathrm{CDCl}_{3}$ at $298 \mathrm{~K}$

\begin{tabular}{|c|c|c|c|c|c|c|c|}
\hline compd & $\begin{array}{l}\delta \mathrm{Ar} \mathrm{O}^{a} \\
\mathrm{~s}(6 \mathrm{H})\end{array}$ & $\begin{array}{l}\delta \mathrm{Ar} \mathrm{E}^{b} \\
\mathrm{~s}(6 \mathrm{H})\end{array}$ & $\begin{array}{c}\delta \mathrm{OCH}_{2} \\
\mathrm{~s}(6 \mathrm{H})\end{array}$ & $\begin{array}{c}8 \mathrm{CH}_{2} \\
\mathrm{AB}^{\circ}(12 \mathrm{H})\end{array}$ & $\begin{array}{l}8 \mathrm{OCH}_{3} \\
8(6 \mathrm{H})\end{array}$ & $\begin{array}{c}\delta \text { tert }-\mathrm{Bu}\left(\mathrm{O}^{\infty}\right) \\
8(27 \mathrm{H})\end{array}$ & $\begin{array}{c}\delta \text { tert-Bu (Ed) } \\
8(27 \mathrm{H})\end{array}$ \\
\hline $\begin{array}{r}3 \\
4 \\
5 \\
9 \\
10 \\
11 \\
12 \\
13 \\
14\end{array}$ & $\begin{array}{l}7.20 \\
7.32 \\
7.18 \\
7.18 \\
7.28 \\
7.27 \\
7.30 \\
7.26 \\
7.27\end{array}$ & $\begin{array}{l}6.56 \\
6.71 \\
6.56 \\
6.61 \\
6.73 \\
6.72 \\
6.66 \\
6.70 \\
6.70\end{array}$ & $\begin{array}{l}4.53 \\
4.96 \\
4.43 \\
4.83 \\
5.06 \\
4.98 \\
\\
5.11 \\
5.10\end{array}$ & $\begin{array}{l}4.46,3.37 \\
4.64,3.40 \\
4.52,3.36 \\
4.49,3.30 \\
4.55,3.42 \\
4.53,3.40 \\
4.49,3.62 \\
4.64,3.41 \\
4.63,3.41\end{array}$ & $\begin{array}{l}2.15 \\
2.26 \\
2.23 \\
2.17 \\
2.31 \\
2.28 \\
2.21 \\
2.30 \\
2.29\end{array}$ & $\begin{array}{l}1.32 \\
1.38 \\
1.47 \\
1.31 \\
1.38 \\
1.38 \\
1.36 \\
1.36 \\
1.37\end{array}$ & $\begin{array}{l}0.71 \\
0.84 \\
0.71 \\
0.74 \\
0.84 \\
0.84 \\
0.78 \\
0.83 \\
0.82\end{array}$ \\
\hline
\end{tabular}

- Aromatic rings substituted with methoxy groups (O rings). "Aromatic rings substituted with substituents other than methoxy groups (E rings).

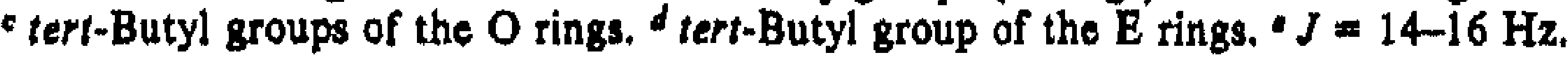

Table 3. ${ }^{\nabla}$ Selected 1 H NMR Data of the 1,2,3-Alternate $\left(C_{3}\right)$ Conformers of 1,3,5-Trimethoxy-2,4,6-trisubstituted p-tert-Buty]calix[6]arenes in $\mathrm{CDCl}_{3}$ at $298 \mathrm{~K}$

\begin{tabular}{|c|c|c|c|c|c|c|}
\hline compd & $\begin{array}{c}\delta \mathrm{Ar} \mathrm{O}^{\infty} \\
2 \mathrm{~d}(2 \mathrm{H}) \mathrm{s}(2 \mathrm{H})\end{array}$ & $\begin{array}{c}\delta \mathrm{Ar} \mathrm{E}^{b} \\
2 \mathrm{~d}(2 \mathrm{H}) \mathrm{s}(2 \mathrm{H})\end{array}$ & $\begin{array}{c}\delta \mathrm{CH}_{2} \\
\mathrm{AB}^{\circ}(4 \mathrm{H})\end{array}$ & $\begin{array}{c}\delta \mathrm{OCH}_{3} \\
8(6 \mathrm{H}) \mathrm{s}(3 \mathrm{H})\end{array}$ & $\begin{array}{c}\delta \text { tert-Bu }\left(O^{\circ}\right) \\
8(18 \mathrm{H}) \mathrm{B}(9 \mathrm{H})\end{array}$ & $\begin{array}{c}8 \text { tert-Bu (Ed) } \\
8(18 \mathrm{H}) \mathrm{s}(9 \mathrm{H})\end{array}$ \\
\hline 3 & $f$ & $f$ & $\begin{array}{l}4.37,3.28 \\
4.19,3.46 \\
4.09,3.60\end{array}$ & 2.231 .96 & $f f$ & 0.780 .88 \\
\hline 4 & $f$ & $f$ & $\begin{array}{l}4.43,3.55 \\
4.22,3.31 \\
4.02,3.83\end{array}$ & 2.141 .89 & 1.351 .42 & 0.981 .29 \\
\hline 5 & $f$ & $f$ & $\begin{array}{l}4.31,3.96 \\
4.09,3.68 \\
4.25,3.30\end{array}$ & 2.301 .97 & 1.411 .47 & 0.921 .06 \\
\hline 9 & $\begin{array}{l}7.097 .08 \\
7.02\end{array}$ & $\begin{array}{l}6,916.69 \\
6.69\end{array}$ & $\begin{array}{l}4.30,3.64 \\
4.25,3.40 \\
4.03,3.70\end{array}$ & 2.262 .04 & 1.111 .24 & 0.950 .95 \\
\hline 10 & $\begin{array}{l}7.177 .10 \\
7.13\end{array}$ & $\begin{array}{l}6.816 .99 \\
6.78\end{array}$ & $\begin{array}{l}4.37,3.50 \\
4.12,3.70 \\
4.30,3.35\end{array}$ & 2.462 .24 & 1.181 .28 & 1.031 .03 \\
\hline 11 & $\begin{array}{l}7.147 .13 \\
7.13\end{array}$ & $\begin{array}{l}7.066 .68 \\
6.72\end{array}$ & $\begin{array}{l}4.32,3.52 \\
4.24,3.32 \\
4.08,3.78\end{array}$ & 2.322 .01 & 1.111 .29 & 1.040 .98 \\
\hline 12 & $\begin{array}{l}7.357 .19 \\
7.13\end{array}$ & $\begin{array}{l}6.896 .64 \\
6.63\end{array}$ & $\begin{array}{l}4.26,3.64 \\
4.22,3.68 \\
4.25,3.73\end{array}$ & 2.141 .89 & 1.301 .34 & 1.030 .99 \\
\hline 13 & $\begin{array}{l}7.197 .16 \\
7.08\end{array}$ & $\begin{array}{l}7.016 .78 \\
6.74\end{array}$ & $\begin{array}{l}4.47,3.35 \\
4.41,3.51 \\
4.19,3.76\end{array}$ & 2.342 .10 & 1.091 .30 & 0.980 .99 \\
\hline 14 & $\begin{array}{l}7.197 .18 \\
7.12\end{array}$ & $\begin{array}{l}7.036 .78 \\
6.74\end{array}$ & $\begin{array}{l}4.45,3.36 \\
4.41,3.52 \\
4.16,3.78\end{array}$ & 2.282 .09 & 1.161 .33 & 1.021 .03 \\
\hline
\end{tabular}

$\nabla$ Notes a-e are mentioned in Table $2 . /$ Due to overlap and/or low abundance of the 1,2,3-alternate conformers, not all resonances could be assigned. Determined at $223 \mathrm{~K}$

mixing times of $0-400 \mathrm{~ms}$, the NOESY data obtained for compound 10 were translated into distances by the initial rate approximation. ${ }^{33}$ The three-dimensional structures of both the flattened cone- and the 1,2,3-alternate conformer of 10 were obtained by using restrained molecular dynamics.

As shown in Figure 3A, the calculated structure of the flattened cone conformer of 10 shows almost perfect $C_{3 v}$ symmetry with the three methoxy substituents pointing into the calix[6]arene annulus. The three aryl groups with the larger substituents form a steep angle with the main average plane through the methylene groups (average of $73^{\circ}$ ). The tert-butyl groups of these aromatic moieties cover the calix[6]arene annulus at the upper rim. The calculated structure for the 1,2,3-alternate conformer is depicted in Figure 3B. Again, all three methoxy groups point inside the annulus: two from one side of the main plane and one from the other side. One of the (3-nitrobenzyl)oxy substituents close to the single methoxy group covers the calix[6]arene additionally. According to these data this 1,2,3-alternate conformation is more specifically designated to $(u, u o, u, d o, d, d o)$. In fact Gutsche et al. ${ }^{14}$ and Pappalardo et al. ${ }^{13 a}$ also observed the occurrence of

(33) Neuhaus, D,; Williamson, M. The Nuclear Overhauser Effect in Structural and Conformational Analysis; VCH Publishers: Cambridge, U.K. 1989. distinguishable conformers of calix[6]arene derivatives. However, here we could elucidate the structure of both conformers.

Interconversion of the Flattened Cone $\left(C_{3 r}\right) / 1,2,3-$ Alternate $\left(C_{n}\right)$ Conformer. In the provious sections it was already noted that the nature of the $\mathrm{E}$ ring substituents has a significant effect on the ${ }^{1} H$ NMR spectral characteristics. Most striking is the variation in the amount of minor $\left(C_{\jmath}\right)$ conformer. From the populations of flattened cone and 1,2,3-alternate conformers present, using the Boltzmann equation, the difference in Gibbs free energy $\left(\Delta G^{\circ}\right)$ was calculated (Table 4). Especially the substitution of different benzylic moieties at the $E$ rings has a remarkable effect on the relative thermodynamic stabilities of the flattened cone conformations. The remarkable kinetic stability of both the flattened cone and 1,2,3-alternate conformations was discussed in qualitative terms in the previous sections. For all compounds, except 4, the rates of interconversion at room temperature have decreased to such an extent that their quantification by NMR becomes rather inaccurate $(k<0.01$ $s^{-1}$ ). These low constants indicate an interconversion pathway with one or more intermediate states of high energy. At $223 \mathrm{~K}$ compounds 10 and 11 exhibit weak and broadened exchange connectivities between the $C_{30}$ cone and a high-energy conformer, most likely an intermediate (in the overall interconversion process) 
A

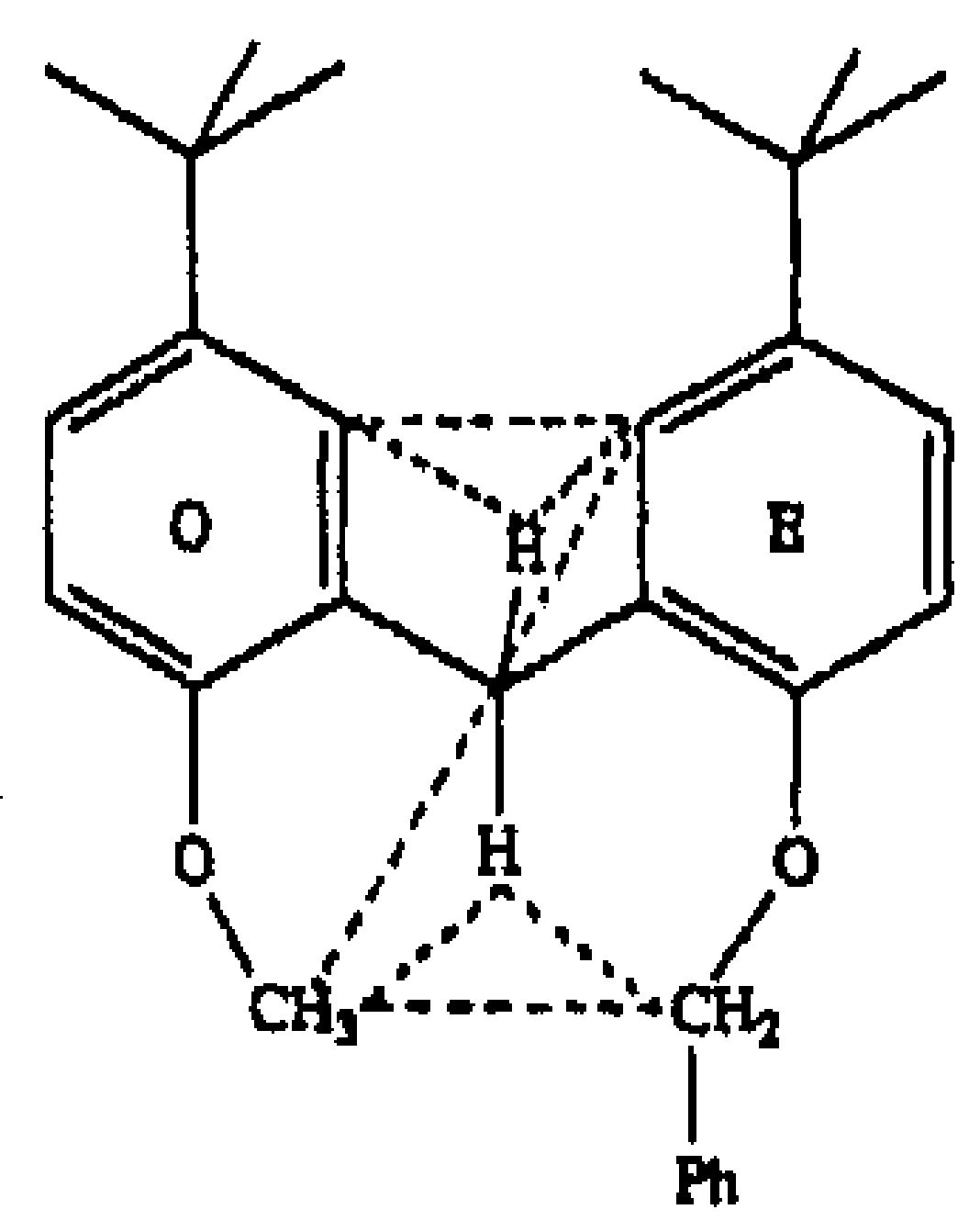

B

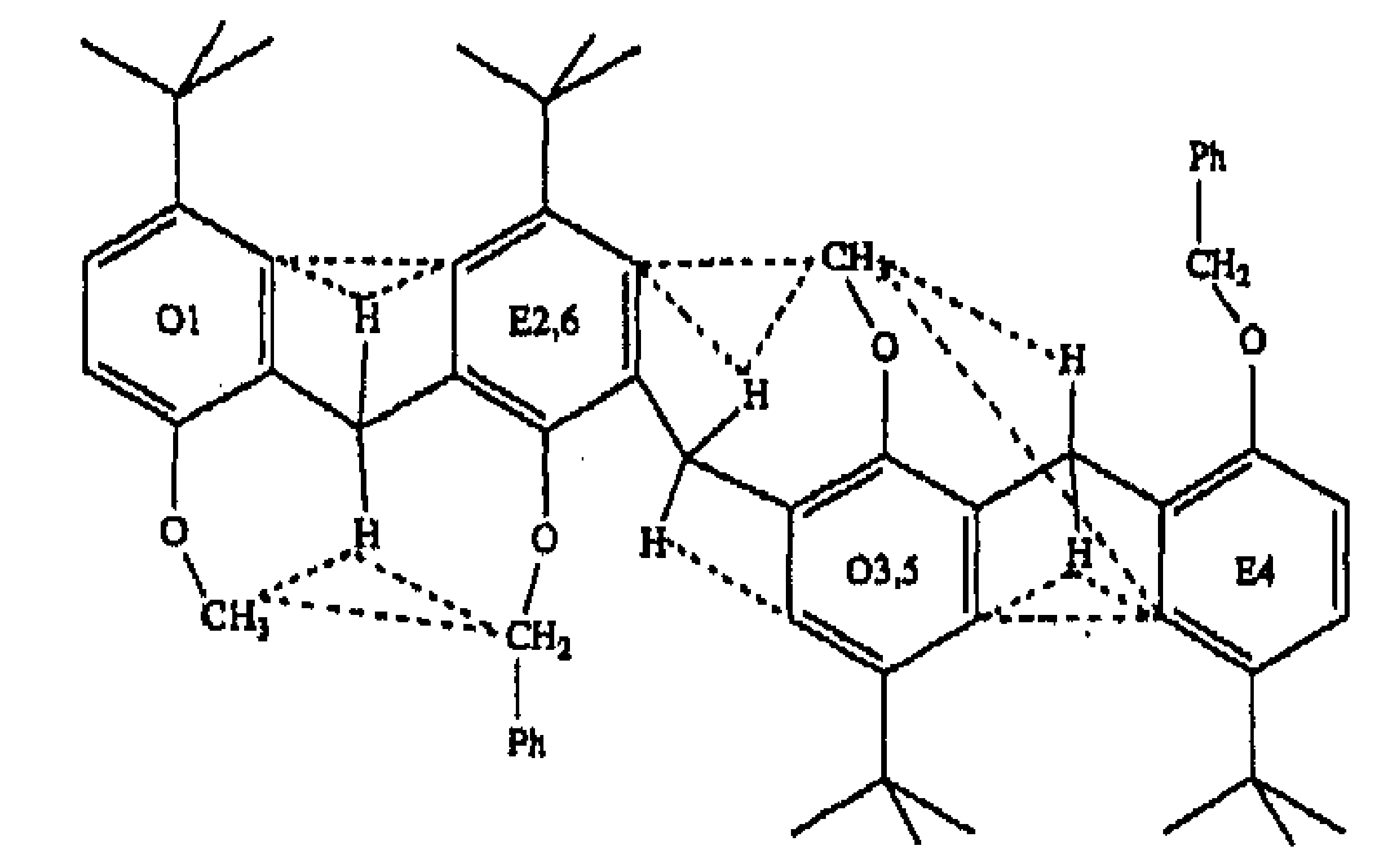

Flgure 2. Through-space connectivities observed in $(A)$ major $\left(C_{30}\right.$ symmetry) and (B) minor ( $C$, symmetry) conformers of 10 as observed by ROESY and NOESY spectroscopy (273 K). For compounds 3-5,9, and 11-14 similar contacts are observed (in the spectra of compound 12 contacts to the methylene group of the substituents of the B rings are absent). In part $A$ only contacts between neighboring rings are presented. In part B only contacts in half of the structure are shown.

in which one or two anisole rings are in an alternate position. Several routes for the overall interconversion are possible, which involve the rotation of an $\mathrm{E}$ ring, via a passage of either the substituent or the tert-butyl group through the annulus and the rotation of two anisole moieties, most probably by the methoxy group through the annulus. There is evidence for a change of mechanism upon an increase in bulkyness of the substituents. From CPK models it was concluded that a (4-phenylbenzyl)oxy moiety cannot pass the annulus. Still interconversion between both the flattened cone and the 1,2,3-alternate conformer is observed, which can only take place via a p-tert-butyl through the annulus mechanism, with a corresponding Gibbs free energy of activation of $88 \mathrm{~kJ} \mathrm{~mol}^{-1}$. An inspection of the data presented in Table 4 indeed reveals a plateau in activation Gibbs frec energy upon an increase in size of the substituents. Most likely, for compounds with an activation Gibbs free energy of less than 82 $\mathrm{kJ} \mathrm{mol}{ }^{-1}$, the rate-limiting step in the interconversion process is the passage of the phenoxy through the annulus. Despite earlier reported results, 14,15 we postulate that substitution of the lower rim with bulky groups is not sufficient to $f(x$ the conformation.

It is known from the literature that the hexasubstituted analogues [hexakis(benzyloxy)-, 21 hexakis $(N, N$-diethylacetamido)-,27 and hexakis[(diethoxyphosphoryl)oxy]-p-tert-butylcalix[6]arenes ${ }^{17}$ ] show fast conformational interconversion at a mbient temperatures. The replacement of the aiternate benzyloxy groups or phosphate groups by methoxy groups considerably raises the activation Gibbs free energy for interconversion. Most likely this Gibbs free energy is derived from self-inclusion of the methoxy substituents. However, self-inclusion alone is not a sufficient constraint to freeze the conformation. This is demonstrated by the large degree of conformational freedom (the signals of the 'H NMR spectra are sharp, while the methylene bridges exhibit one singlet) of derivatives 2 and $6-8$, bearing relatively small substituents, and of compound 19 , the partially de-tert-butylated analogue of 10. A combination of self-inclusion of the methoxy groups and bulky substituents (tert-butyl groups) at the para positions as well at the phenolic oxygen of the $E$ rings provides
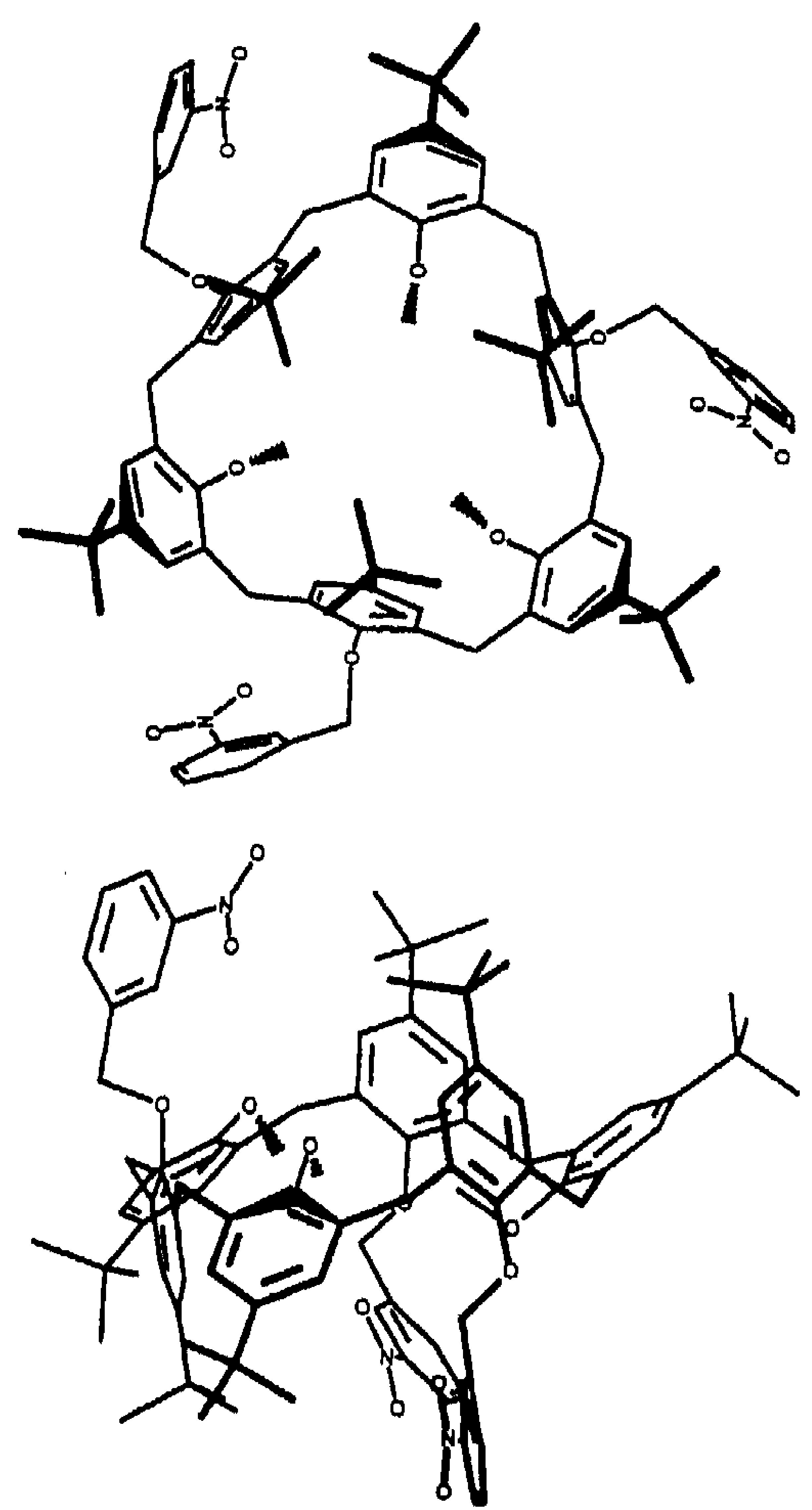

Figure 3. Drawing of the three-dimensional structures of ( $A$, top) the major $(u, u 0, u, u 0, u, u o)$ (top view) and (B, bottom) the minor $(u, u 0, u-$ ,do,d,do) (top view) conformers of 10, obtained by RMM/RMD, using 600-MHz NOESY data. H atoms are omitted for clarity.

Table 4. Thermodynamic and Kinetic Parameters for the Interconversion (in $\mathrm{CDCl}_{3}$ ) of Flattened Cone $\left(C_{30}\right)$ and 1,2,3-Alternate $\left(C_{s}\right)$ Conformers of the 1,3,5-Trimethoxy-2,4,6-trisubstituted p-tertButylcalix[6]arenes

\begin{tabular}{ccc}
\hline compd & $\begin{array}{c}\Delta G^{\circ}(T=303 \mathrm{~K})^{a} \\
\mathrm{~kJ} \mathrm{~mol}-1\end{array}$ & $\begin{array}{c}\Delta G^{*}(T=328 \mathrm{~K})^{c} \\
\mathrm{~kJ} \mathrm{~mol})^{-1}\end{array}$ \\
\hline 3 & 7 & 87 \\
4 & $3^{b}$ & $70^{c}$ \\
5 & 6 & 78 \\
9 & 2 & 86 \\
10 & 2 & 80 \\
11 & 3 & 82 \\
12 & 4 & 80 \\
13 & 3 & 85 \\
14 & 3 & 88 \\
\hline
\end{tabular}

- Experimental error $\pm 1 \mathrm{~kJ} \mathrm{~mol}^{-1}$. ${ }^{b}$ Determined at $223 \mathrm{~K}$. $~$ Extrapolated value from kinetic measurements in the temperature range 243$283 \mathrm{~K}$.

a means to suppress the interconversion process and to control the conformation.

The self-inclusion of the methoxy groups leads to a weak $\mathrm{CH} \cdots x$ interaction, ${ }^{34}$ between the polarized methyl groups and the

(34) (a) Nishio, M.; Hirota, M. Tetrahedron 1989, 15, 7201-7245 and references cited therein. (b) Kobayashi, $K_{\text {; }}$ Asakawa, $Y$; Kikuchi, $Y$; Toi, H.; Aoyama, Y. J. Am. Chem. Soc. 1993, 115, 2648-2654. (c) Andreetti, G. D.; Ori, O.; Ugozzoli, F.; Alfieri, C.; Pochini, A.; Ungaro, R. J. Inclustion Phenom. 1988, 6, 523-536. 
electron-rich aromatic rings of the cavity. The strength of this interaction can be estimated from the difference in activation Gibbs free energy for the interconversion process of the $C_{30}$ derivatives and their hexasubstituted analogues. We assume that in both cases the rate-limiting step, the movement of the bulky $O$-substituent through the annulus, is the same. From data we determined for the hexasubstituted calix [6]arenes $\left[57 \mathrm{~kJ} \mathrm{~mol}^{-1}\right.$ for the hexakis(benzyloxy)- and $59 . \mathrm{kJ}$ mol-1 for the hexakis[(diethoxyphosphoryl)oxy]-p-tert-butylcalix[6]arene] we estimate that $13-21 \mathrm{~kJ} \mathrm{~mol}^{-1}$ is added to the activation Gibbs free energy upon the inclusion of the three methoxy groups. 35 This value is in line with the outcome of our modeling studies, which predict a gain in Gibbs free energy of approximately $8 \mathrm{~kJ} \mathrm{~mol}^{-1}$ per methoxy moiety.

Variable-Temperature Studies of the Ethoxy and Propoxy Derivatives 16 and 17. The results obtained for the 1,3,5. trimethoxycalix [6]arene derivatives led to further investigations of the concept of self-inclusion. To investigate the interplay of an increase in $\mathrm{CH} \cdot \cdots \pi$ interactions on one side and an increase in steric hindrance on the other side, the 1,3,5-triethylated and -tripropylated derivatives 16 and 17 , respectively, were synthesized.

Figure 4A shows the variable-temperature 'H NMR series of triethyl derivative 16. From the spectra at room temperature it is concluded that, like compound 3 , there exists a dynamic equilibrium between a predominant cone-like $C_{3 \nu}$ conformer and a minor conformer, with a high activation Gibbs free energy of interconversion. Upon cooling (temperature range 193-353 K), the signals of the minor conformer remain sharp, while exchange line broadening of the $C_{30}$ conformer indicates that its symmetry is in fact time averaged. NOESY exchange connectivities in combination with DQF- and TQF-COSY data indicate that at $193 \mathrm{~K}$ the $C_{3 n}$ conformer interconverts with a $C_{s}$ conformer, which is present in low concentration $(<10 \%)$. This $C_{s}$ conformer is characterized by one low-field degenerate $\left(\mathrm{A}_{2} \mathrm{X}_{3}\right)$ ethoxy spin system and one extremely upfield, nondegenerate $\left(\mathrm{AMX}_{3}\right)$ ethoxy spin system of intensity ratio 1:2 (Figure 4). These features indicate that two ethoxy groups (not located in the mirror plane) are deeply embedded in the calix[6]arene cavity, in a manner that restricts their rotational freedom, while one ethoxy group is located at the periphery of the cavity (its degeneracy can equally be explained by either its rotational freedom or its location in the mirror plane). The low activation Gibbs free energy for the $C_{30}-$ $C_{3}$ interconversion excludes the passage of a tert-butyl- or an acetamido group through the annulus, while the severe exchange broadening of other than ethoxy resonances argues against simple rearrangement of the ethoxy groups in the annulus. In analogy to the high-energy methoxy alternate intermediate observed for derivative 3 (vide supra), most likely one or two of the ethoxy groups rotate through the annulus to produce an 'ethoxy' alternate $C_{s}$ conformer (1- or 1,3-alternate). The increase of the activation free energy upon self-inclusion of the ethoxy groups also stabilizes the 'cone-like' arrangement of the $\mathrm{E}$ rings.

At ambient temperatures, the 'H NMR spectrum of 17 (the propyl analogue of 3, Figure 4B) shows multiple resonances for the methylene and aromatic protons, pointing to either several conformers or a low-symmetry single conformer. The three propoxy groups appear as three spin systems with nearly degenerate methylene resonances. The upfield shifts $(-0.2$ to 0.8 ppm) of two propoxy groups indicate their inclusion in the calix[6] arene cavity, while one propoxy group is located at its periphery. Low-temperature (193 K) TOCSY, DQF, and TQF-COSY

(35) The Gibbs free energy requirement for movement of the bulky substituent in the $C_{30}$ conformers should not differ dramatically from that for the corresponding movement in the hexasubatituted analogues. However, the interconversion trajectory differs with respect to the movement of the methoxy units out of the cavity, This movement requires an extra amount of frec energy which adds up to the total activation Gibba free energy barrier. To a rough approximation one may assume that this additjonal frec energy equals the strength of the CH...x interactions.

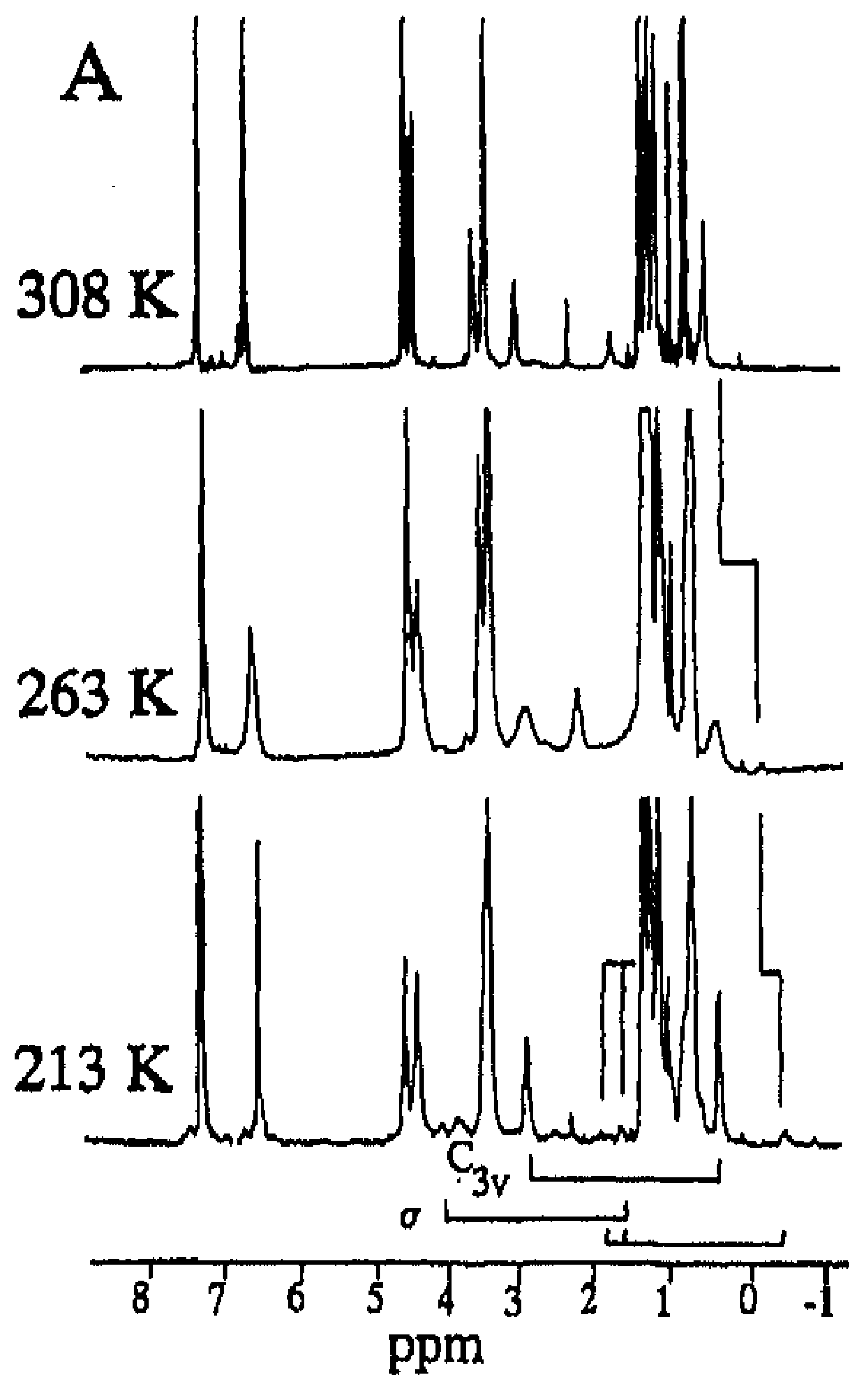

B

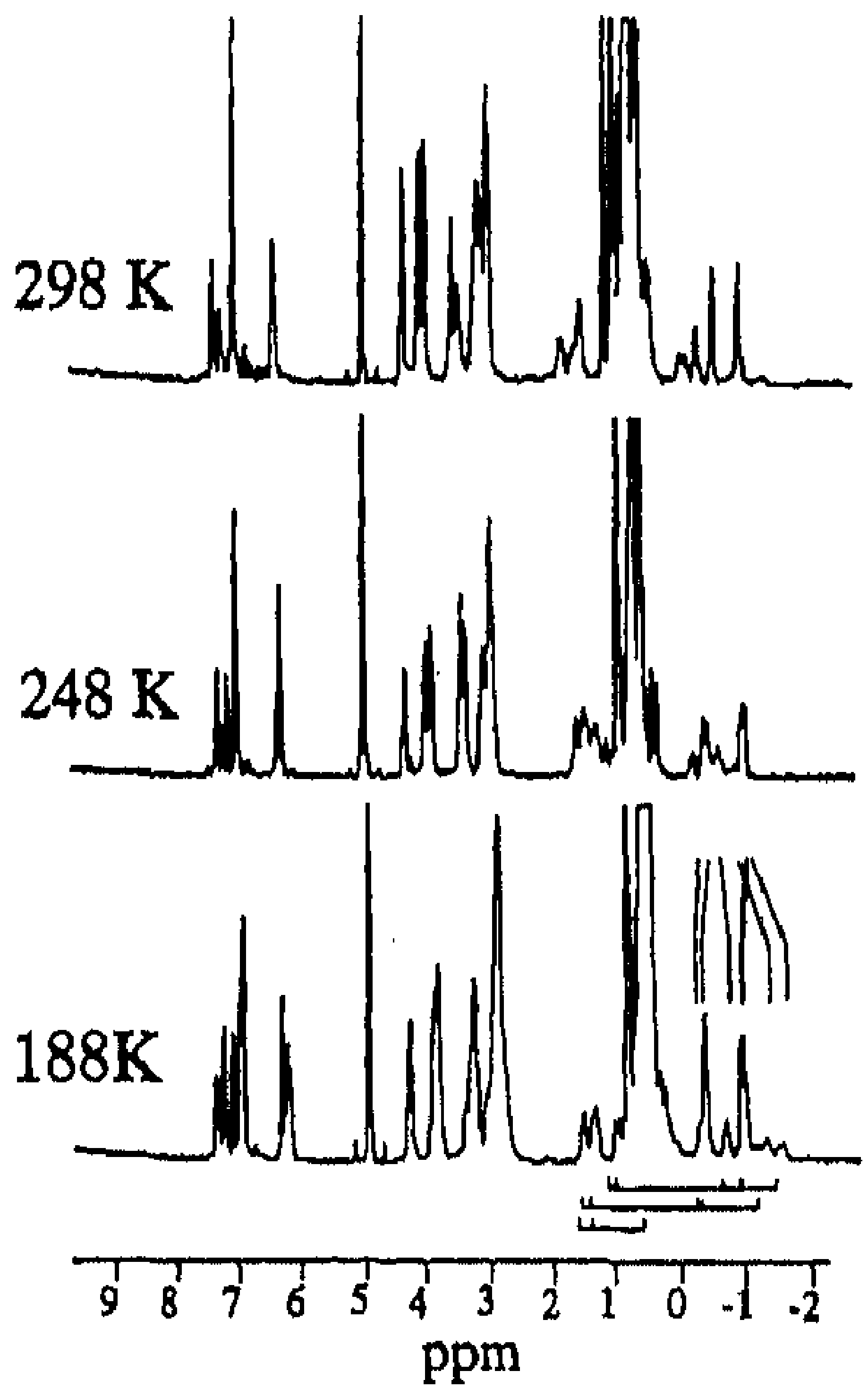

Figure 4. IH NMR temperature series conducted on compounds $16(\mathrm{~A})$ and 17 (B) (CDCl 3 and $\mathrm{CD}_{2} \mathrm{Cl}_{2,}$ respoctively). The tracks of the ethoxy (A) and propoxy (B) resonances have been indicated.

experiments reveal two pairs of nondegenerate and one pair of nearly degenerate methylene resonances.

The presence of multiple conformers can be excluded by a combination of a TOCSY experiment (Figure 5A), which shows four pairs of $J$-coupled $(J=2 \mathrm{~Hz}$ ) aromatic proton resonances, and a ROESY experiment, showing their spatial proximity (Figure 5B). Unfortunately, substituent-specific assignments could not be made, because of severe overlap in HMQC/HMBC experiments. However, the TOCSY/ROESY walks depicted in Figure SB provide sufficient evidence for 17 to be in a 1,2,3-alternate conformation. The observation of three separate spin systems for the propoxy groups proves their nonsymmetric accommodation in the annulus. The coalescence of these spin systems upon an increase of the temperature indicates dynamic rearrangement of these groups. At ambient temperature the aromatic resonances 

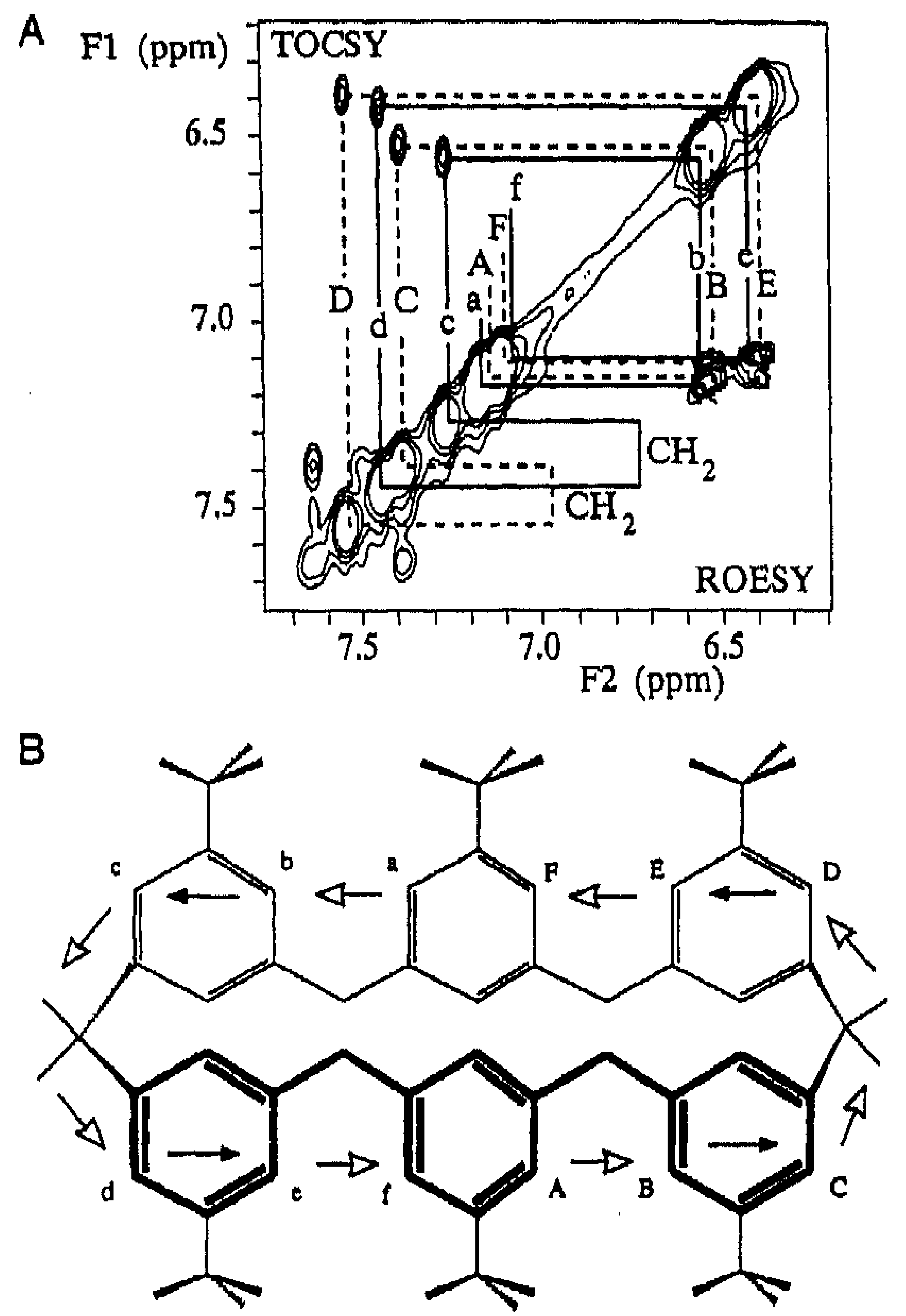

Figure 5. (A) 400-MHz (MLEV17) TOCSY (above the diagonal) and ROESY spectrum (below the diagonal) of 17, recorded at 195K. Mixing times were 30 and $300 \mathrm{~ms}$, respectively. (B) 1,2,3-Alternate conformation of 17 as derived from the contacts in part $A$. Combined through-bond (TOCSY) and through-space (ROESY) walks correspond with the walks in part $A$

show some exchange broadening, but in a NOESY experiment only weak exchange connectivities can be observed in this region, from which it was concluded that total ring interconversion is a relatively slow process. This means that enlargement of the alkyl group to propyl renders an asymmetric 1,2,3-alternate conformation more favorable

\section{Conclusions}

For 1,3,5-trialkoxy-2,4,6-trisubstituted calix[6]arenes, the conformation, as well the kinetic stability, can be controlled by self-inclusion of alkyl groups. The conformation is confined preferentially to a cone if $\mathrm{R}=$ methyl or ethyl. Particularly effective in reducing the conformational flexibility are methoxy groups at the 1,3,5 positions, which are self-included inside the cavity and stabilize the cone-like conformation through weak CH... $\pi$ interactions. However, a complete blocking of a conformation is not possible due to the operation of a dual interconversion mechanism. ${ }^{36}$ When the lower rim substituents increase in size, the interconversion between the flattened cone and the 1,2,3-alternate conformation can occur via the p-tertbutyl through the annulus pathway, with a Gibbs free energy of activation of $88 \mathrm{~kJ} \mathrm{~mol}^{-1}(T=328 \mathrm{~K})$. The concept of selfinclusion might be generalized and applied to other substituted calix [6]arenes, in order to control their conformation for the design of new large ca vities for molecular recognition. We are currently exploring such possibilities.

(36) After submission of the manuscript we became aware of the following recent papers of Shinkaj and co-workers, in which also a "tert-butyl through

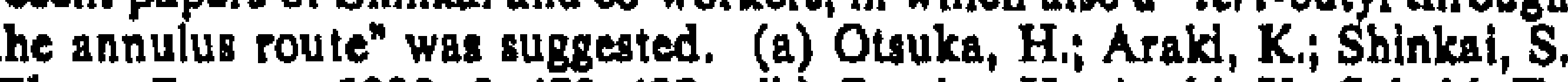
Chem. Express 1993, 8, 479-482. (b) Otsuka, H.; Araki, K.; Sakaki, T.; Nakashima, K.; Shinkai, S. Tetrahedron Lett. 1993, 34, 7275-7278.
Chart 2<smiles>CC(C)(C)c1cc(O)c(O)c(Cc2cc(C(C)(C)C)cc(Cc3cc(C(C)(C)C)cc(Cc4cc(C(C)(C)C)cc(Cc5cc(C(C)(C)C)cc(Cc6cc(C(C)(C)C)cc(C(C)(C)C)c6O)c5O)c4O)c3O)c2O)c1</smiles>

Experimental Section

Melting points are uncorrocted. $1 \mathrm{H}$ and ${ }^{13} \mathrm{C}$ NMR were recorded on Bruker and Varian instruments in $\mathrm{CDCl}_{3}$ with Mesi as an internal standard, unless stated otherwise. Preparative column chromatography separations were performed on Merck silica gel 60 (230-400 mesh) while procoa ted silica gel plates (Merck, $60 \mathrm{~F}_{254}$ ) were used for analytical TLC. FAB mass spectra were performed on Finnigan MAT 90 and VG AutoSpec spectrometers, with m-nitrobenzyl alcobol as a matrix. All solvents wero purified by standard procedures. Hexane refers to the fraction with bp $60-80^{\circ} \mathrm{C}$. All other chemicals were analytically pure and were used without further purification. Analytical samples were dried over phosphorus pentoxide at $100^{\circ} \mathrm{C}$ for $24 \mathrm{~h}$. 1,3,5-Trimethoxyp-tert-butylcalix[6]arene (1) ${ }^{16}$ and 1,3,5-trimethoxy-2,4,6-tris $(N, N$ diethylacetamido)-p-sert-butylcalix [6] arene ${ }^{27}$ were prepared according to literature procedures. Selocted ' $H$ NMR data of compounds 3-5 and 9-14 have been summarized in Tables 2 and 3. The official numbering of the calix[6]arene skeleton is presented in Chart 2.

38, 40,42-Tris (acetoxy)-5,11,17,23,29,35-hexalin(1,1-dimethylethyl)37,39,41-trimethoxycalixx 6) reno (2). Thallium(1) ethoxide ( $23 \mu \mathrm{L}, 0.325$ $\mathrm{mmol}$ ) was added to a solution of $1(100 \mathrm{mg}, 0.098 \mathrm{mmol})$ in dry diethyl ether $(10 \mathrm{~mL})$. After the solution was stirred for $30 \mathrm{~min}$ at room temperature, a solution of acetyl chloride $(26 \mathrm{~mL}, 0.365 \mathrm{mmol})$ in diethyl ether $(5 \mathrm{~mL})$ was added dropwise. After $2 \mathrm{~h}$ the reaction was quenched with $10 \% \mathrm{HCl}(30 \mathrm{~mL})$ and diethyl ether $(20 \mathrm{~mL})$ was added. The organic phase was washed with water $(2 \times 15 \mathrm{~mL})$ and dried over $\mathrm{Na}_{2-}$ $\mathrm{SO}_{4}$. After evaporation, the crude solid was recryatallized from $\mathrm{MeOH}$ to give pure 2: yield $96 \mathrm{mg}(86 \%)$; $\mathrm{mp} 284-286^{\circ} \mathrm{C}$ (MeOH); ' $\mathrm{H}$ NMR (100 MHz) 87.14, 6.82 (s, 6 H, ArH), $3.78(\mathrm{bs}, 12 \mathrm{H}, \mathrm{ArCH}, \mathrm{Ar}), 3.23$ $(s, 9 \mathrm{H}, \mathrm{OCH})_{3}, 1.69\left(\mathrm{bs}, 9 \mathrm{H}, \mathrm{CH}_{3} \mathrm{CO}\right), 1.26,1.10\left(8,27 \mathrm{H}, \mathrm{C}\left(\mathrm{CH}_{3}\right)_{3}\right)$; ${ }^{13} \mathrm{C}$ NMR $(62.5 \mathrm{MHz}) \delta 169.1(\mathrm{~s}, \mathrm{C}-0), 153.4,145.9,148.2,145.2$, $132.6,132.0(\mathrm{~s}, \mathrm{ArC}), 126.3,125.4$ (d, ArC), $60.0\left(\mathrm{q}, \mathrm{OCH}_{3}\right), 34.3,34.1$ $\left(\mathrm{s}, \mathrm{C}\left(\mathrm{CH}_{3}\right)_{3}\right), 31.5(\mathrm{t}, \mathrm{ArCH}, \mathrm{Ar}), 31.4,31.3\left(\mathrm{q}, \mathrm{C}\left(\mathrm{CH}_{3}\right)_{3}\right), 20.0\left(\mathrm{q}, \mathrm{CH}_{3-}\right.$ $\mathrm{CO})$; MS (CI) $\mathrm{m} / \mathrm{e} 1140.2\left(\mathrm{M}^{+}\right.$, calod 1140.8). Anal. Calod for $\mathrm{C}_{75} \mathrm{H}_{96} \mathrm{O}_{9}: \mathrm{C}, 78.93 ; \mathrm{H}, 8.47$. Found: C, 78.84; $\mathrm{H}_{1}, 8.51$.

General Procedures for the Alkylation of 1,3,5-Trimethoxy-p-tertbutyleallix 6)arene (1), Procedure A. Compound $1(0.51 \mathrm{~g}, 0.50 \mathrm{mmol})$ was added to a suspension of $\mathrm{NaH}$ ( $50 \%$ in oil, $0.14 \mathrm{~g}, 3 \mathrm{mmol}$ ) in dry THF $(60 \mathrm{~mL})$. The mixture was refluxed for $0.5 \mathrm{~h}$, whereupon the appropriate alkyl halide (12 equiv, $6 \mathrm{mmol}$ ) was added and refluxing was continued for $16-24 \mathrm{~h}$. After evaporation of the solvent, the residue was quenchod with $2 \mathrm{~N} \mathrm{HCl}(50 \mathrm{~mL})$ and extracted with $\mathrm{CH}_{2} \mathrm{Cl}_{2}(2 \times 50$ $\mathrm{mL})$. The organic layer was washed with water $(50 \mathrm{~mL})$ and dried over $\mathrm{MgSO}_{4}$. The crude products were purifiod by trituration or recrystallization.

Procedure B. A suspension of $1(100 \mathrm{mg}, 0.098 \mathrm{mmol})$, an alkyl halide (6 equiv, $0.59 \mathrm{mmol}$ ), and $\mathrm{Cs}_{2} \mathrm{CO}_{3}(192 \mathrm{mg}, 0.59 \mathrm{mmol}$ ) in dry DMF (15 
$\mathrm{mL}$ ) was'stirred at $70^{\circ} \mathrm{C}$ for $18 \mathrm{~h}$. The solvent was oraporated, and the residue was taken up in $\mathrm{CH}_{2} \mathrm{Cl}_{2}(100 \mathrm{~mL})$. The organic layer was washed with $1 \mathrm{~N} \mathrm{HCl}(3 \times 50 \mathrm{~mL})$ and brine $(25 \mathrm{~mL})$ and dried over $\mathrm{MgSO}_{4}$. The crude products were purified by trituration or recrystallization.

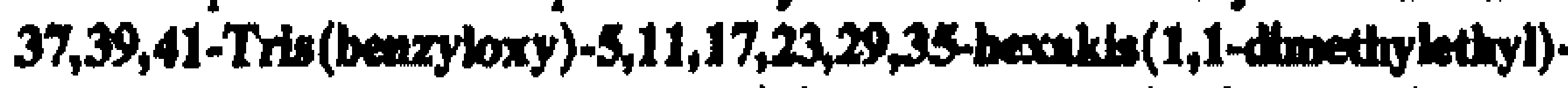
$38,40,42$-trimethoxycallix (6) arene (4) was synthesized according to procedure A with benzyl chloride $(0.69 \mathrm{~mL})$. The crude product was recrystallized from $\mathrm{CH}_{2} \mathrm{Cl}_{2}$ /hexane to give pure 4: yield $450 \mathrm{mg}$ (70\%); $\mathrm{mp}>350^{\circ} \mathrm{C} ;{ }^{13} \mathrm{CNMR}(62.5 \mathrm{MHz}) \delta 145.8,134.0,133.3,128.5,128.1$ 124.1, 123.7 (ArC, PhC), 74.6 (t, OCH $), 60.2\left(\mathrm{q}, \mathrm{OCH}_{3}\right), 34.3,34.2$ (s, $\left.\mathrm{C}\left(\mathrm{CH}_{3}\right)_{3}\right), 31.7,31.3\left(\mathrm{a}, \mathrm{C}\left(\mathrm{CH}_{3}\right)_{3}\right), 29.8(\mathrm{t}, \mathrm{ArCH}, \mathrm{Ar}) ; \mathrm{MS}$ (FAB) $m / e$ 1285.3 $\left(\mathrm{M}^{+}\right.$, caled 1284.9). Anal. Caled for $\mathrm{C}_{90} \mathrm{H}_{100} \mathrm{O}_{6}: \mathrm{C}, 84.07$; H, 8.46. Found: C, 83.96; H, 8.54.

5,11,17,23,29,35-Hexukio(1,1-dimethylethy) $)-37,39,41-$ trif $f((1,1-d 1-$ methylethyl)oxy) carbonyl) wethoxy]-38,40,42-timethoxy callix[6]arene (5) was synthesized according to procedure A using tert-butyl bromoacetste $(0.97 \mathrm{~mL})$. The crude product was recrystallized from $\mathrm{CH}_{2} \mathrm{Cl}_{2} / \mathrm{McOH}$ to give pure S: yield $530 \mathrm{mg}(78 \%) ; \mathrm{mp} 231-233^{\circ} \mathrm{C}\left(\mathrm{CH}_{2} \mathrm{Cl}_{2} / \mathrm{MeOH}\right)$; ${ }^{13} \mathrm{C}$ NMR (62.5 MHz) $\delta 166.4(s, \mathrm{C}=0), 154.7,151.7,146.1,145.7$, $133.5,133.0(\mathrm{~s}, \mathrm{ArC}), 128.1,123.6(\mathrm{~d}, \mathrm{ArC}), 70.1(\mathrm{t}, \mathrm{OCH}), 60.1(\mathrm{q}$ $\left.\mathrm{OCH}_{3}\right), 34.2,34.0\left(\mathrm{~s}, \mathrm{C}\left(\mathrm{CH}_{3}\right)_{3}\right), 31.7,31.2\left(\mathrm{q}, \mathrm{C}\left(\mathrm{CH}_{3}\right)_{3}\right), 30.1\left(\mathrm{t}, \mathrm{ArCH}_{2}\right.$ $\mathrm{Ar}), 29.7\left(8, \mathrm{COOC}\left(\mathrm{CH}_{3}\right)_{3}\right), 28.2\left(\mathrm{q}, \mathrm{COOC}\left(\mathrm{CH}_{3}\right)_{3}\right) ; \mathrm{MS}(\mathrm{FAB}) \mathrm{m} / \mathrm{e}$ 1357.0 (M+, calcd 1357.6). Anal. Calcd for $\mathrm{C}_{17} \mathrm{H}_{120} \mathrm{O}_{12} ; \mathrm{C}, 76.96 ; \mathrm{H}$, 8.90. Found: C. $76.89 ; \mathrm{H}, 9.01$.

37,39,41-Tris (carboxylmethoxy)-5,11,17,23,29,35-hoxalkis (1,1-dimethylethyl)-38,40,42-trimethoxycallx (6jarene (6). A suspersion of triester $5(500 \mathrm{mg}, 0.37 \mathrm{mmol})$ in trifluoroscetic acid $(10 \mathrm{~mL})$ was stirred at room temperature for $5 \mathrm{~h}$. The solvent was evaporated, and the residue was triturated with water to give pure 6: yield $370 \mathrm{mg}(85 \%)$; mp 292$294^{\circ} \mathrm{C}_{i}{ }^{1} \mathrm{H}$ NMR (100 MHz) \& 7.00, 6.90 (s, $\left.6 \mathrm{H}, \mathrm{ArH}\right), 4.0-3.4$ (bs, $\left.18 \mathrm{H}, \mathrm{ArCH}, \mathrm{Ar}, \mathrm{OCH}_{2}\right), 3.72(\mathrm{~s}, 9 \mathrm{H}, \mathrm{OCH}), 1,88\left(8,54 \mathrm{H}, \mathrm{C}\left(\mathrm{CH}_{3}\right)_{3}\right)$ ${ }^{13} \mathrm{C}$ NMR (62.5 MHz) $\delta 170.9(\mathrm{~s}, \mathrm{C}=0), 153.2,151.1,146.7,146.3$ 133.1, 132.7, (s, ArC), 126.1, $125.9(\mathrm{~d}, \operatorname{ArC}), 72.1\left(\mathrm{t}, \mathrm{OCH}_{2}\right), 60.7(\mathrm{q}$ $\left.\mathrm{OCH}_{3}\right), 34.4,34.2,\left(\mathrm{~s}, \mathrm{C}\left(\mathrm{CH}_{3}\right)_{3}\right), 31.7,31.4\left(\mathrm{q}_{1} \mathrm{C}\left(\mathrm{CH}_{3}\right)_{3}\right), 30.1\left(\mathrm{t}, \mathrm{ArCH}_{2}\right.$ Ar): MS (EI) m/e 1188.7 [(M-H) ${ }^{+}$, calcd 1188.9]. Anal. Calcd for $\mathrm{C}_{75} \mathrm{H}_{96} \mathrm{O}_{12}: \mathrm{C}_{1} 75.73 ; \mathrm{H}, 8.13$. Found: $\mathrm{C}, 75.61 ; \mathrm{H}, 8.22$.

$5,11,17,23,29,35$-Hexakis (1,1-dimethylethyl) -38,40,42-trimethoxy. 37,39,41-tris (2-propenyloxy) callix 6 Garene (7) was synthesized according to procedure $A$ with allyl bromide $(0.52 \mathrm{~mL})$. The crude product was triturated with hexane and recrystallized from ethanol to give pure 7: yield $505 \mathrm{mg}$ (89\%); mp 261-263 ${ }^{\circ} \mathrm{C}$ (EtOH); 'H NMR (250 MHz) 8 $7.20,6.82(\mathrm{~s}, 6 \mathrm{H}, \mathrm{ArH}), 6.05-5.85\left(\mathrm{~m}, 3 \mathrm{H}, \mathrm{CH}-\mathrm{CH}_{2}\right), 5.3-5.0(\mathrm{~m}, 6$ $\left.\mathrm{H}, \mathrm{CH}=\mathrm{CH}_{2}\right), 4.15\left(\mathrm{~d}, J=4.8 \mathrm{~Hz}, 6 \mathrm{H}, O \mathrm{CH}_{2}\right), 3.94\left(\mathrm{bs}, 12 \mathrm{H}, \mathrm{ArCH}_{2}-\right.$ Ar), $2.52\left(\mathrm{~s}, 9 \mathrm{H}_{1} \mathrm{OCH}_{3}\right), 1.30,0.96\left(\mathrm{~s}, 27 \mathrm{H}, \mathrm{C}\left(\mathrm{CH}_{3}\right)_{3}\right) ;{ }^{13} \mathrm{C}$ NMR (50 $\mathrm{MHz}) \delta 154.4,152.3,134.0,133.6,133.1$ (\&, ArC), 145.6 (d, CHm), $127.3,124.6(\mathrm{~d}, \mathrm{ArC}), 117.0\left(t, \mathrm{CH}_{2}-\mathrm{m}\right), 73.3\left(\mathrm{t}, \mathrm{OCH}_{2}\right), 60.1\left(\mathrm{q}, \mathrm{OCH}_{3}\right)$, $34.2,34.0\left(\mathrm{~s}, \mathrm{C}\left(\mathrm{CH}_{3}\right)_{3}\right), 31.5,31.2\left(\mathrm{q}, \mathrm{C}\left(\mathrm{CH}_{3}\right)_{3}\right), 30.6\left(\mathrm{t}, \mathrm{ArCH}_{2} \mathrm{Ar}\right)$; MS (FAB) $m / e 1134.5\left(\mathrm{M}^{+}\right.$, calcd 1134.7). Anal. Caled for $\mathrm{C}_{78} \mathrm{H}_{102} \mathrm{O}_{6}: \mathrm{C}, 82.48 ; \mathrm{H}, 9.06$. Found: $\mathrm{C}, 82.07, \mathrm{H}, 9.11$.

$5,11,17,23,29,35$-Hexakis (1,1-dimethylethyl)-38,40,42-trimethoxy 37,39,41-tris (2-propynaloxy) callx [6) arene (8) was synthesized according to procedure A with propargyl bromide $(0.45 \mathrm{~mL})$. The crude product was recrystallized from methanol to give pure 8: yield $480 \mathrm{mg}(85 \%)$; mp 242-243 ${ }^{\circ} \mathrm{C}(\mathrm{MeOH})$; ' $\mathrm{H}$ NMR $\left(\mathrm{CD}_{2} \mathrm{Cl}_{2}, 250 \mathrm{MHz}\right) 87.16,6.72$ (s, $6 \mathrm{H}$, ArH) $, 5.23(\mathrm{~d}, J=2.1 \mathrm{~Hz}, 3 \mathrm{H}, \mathrm{CH}), 4.34(\mathrm{~d}, J=2.3 \mathrm{~Hz}$, $\left.6 \mathrm{H}, \mathrm{OCH}_{2}\right), 3.89\left(\mathrm{~s}, 12 \mathrm{H}, \mathrm{ArCH}_{2} \mathrm{Ar}\right), 2.37\left(\mathrm{~s}, 9 \mathrm{H}, \mathrm{OCH}_{3}\right), 1.25,0.85$ $\left(s, 27 \mathrm{H}, \mathrm{C}\left(\mathrm{CH}_{3}\right)_{3}\right) ;{ }^{13} \mathrm{C}$ NMR $\left(\mathrm{CD}_{2} \mathrm{Cl}_{2}, 62.5 \mathrm{MHz}\right) \& 154.4,151.9$, $145.6,133.8,133.6,132.9(\mathrm{~s}, \mathrm{ArC}), 127.4,124.7(\mathrm{~d}, \mathrm{ArC}), 79.6(\mathrm{~d}, \mathrm{CH})$, $74.9\left(\mathrm{t}, \mathrm{OCH}_{2}\right), 60.1(\mathrm{~g}, \mathrm{OCH}), 34.2,34.1,\left(\mathrm{~s}, \mathrm{C}\left(\mathrm{CH}_{3}\right)_{3}\right), 31.5,31.2(\mathrm{q}$, $\left.\mathrm{C}\left(\mathrm{CH}_{3}\right)_{3}\right), 31.1\left(\mathrm{t}, \mathrm{ArCH} \mathrm{CH}_{2} \mathrm{Ar}\right.$; MS (FAB) m/e $1129.0\left(\mathrm{M}^{+}\right.$, calod 1128.7). Anal. Calcd for $\mathrm{C}_{78} \mathrm{H}_{96} \mathrm{O}_{6}: \mathrm{C}, 82.94 ; \mathrm{H}, 8.57$. Found: $\mathrm{C}, 83.15 ; \mathrm{H}$, 8.58

37,39,41-Tris (4-bromobenzyl) oxy\}-5,11,17,23,29,35-bexakls(1,1-dlmethylethyl)-38,40,42-trimethoxycalix\{6\}rene (9) was synthesized according to procedure A with 4-bromobenzyl bromide ( $1.50 \mathrm{~g})$. The crude product was recrystallized from $\mathrm{CH}_{2} \mathrm{Cl}_{2} / \mathrm{MeOH}$ to give pure 9; yield $670 \mathrm{mg}(88 \%) ; \mathrm{mp} 158-161^{\circ} \mathrm{C}\left(\mathrm{CH}_{2} \mathrm{Cl}_{2} / \mathrm{M}=\mathrm{OH}\right)$; $^{15} \mathrm{CNMR}$ (62.5 MHz) $\delta\left(C_{3 v}\right.$ conformer) $154.4,151.4,146.0,145.9,136.7,133.7,133.0(\mathrm{~s}$, $\operatorname{ArC}), 131.6,129,6,128.0,123.7(\mathrm{~d}, \mathrm{ArC}), 121.8(\mathrm{~s}, \mathrm{ArC}), 73.8\left(\mathrm{t}, \mathrm{OCH}_{2}\right)$, $60.2\left(\mathrm{q}, \mathrm{OCH}_{3}\right), 34.2,34.0\left(\mathrm{~s}, \mathrm{C}\left(\mathrm{CH}_{3}\right)_{3}\right), 31.6,31.1\left(\mathrm{q}, \mathrm{C}\left(\mathrm{CH}_{3}\right)_{3}\right), 29.8$ (t, $\mathrm{ArCH}, \mathrm{Ar}) ; \mathrm{MS}(\mathrm{Cl}) \mathrm{m} / \mathrm{e} 1518.3\left(\mathrm{M}^{+}\right.$, caled for $\mathrm{C}_{95} \mathrm{H}_{105}{ }^{79} \mathrm{Br}_{3} \mathrm{O}_{6}$ 1518.6). Anal. Caled for $\mathrm{C}_{90} \mathrm{H}_{103} \mathrm{Br}_{3} \mathrm{O}_{6} ; \mathrm{C}, 71.0 ; \mathrm{H}, 6.95$. Found; $\mathrm{C}$, $70.92 ; \mathrm{H}, 7.01$.

5,11,17,23,29,35-Hexakis (1,1-dimethylethyl)-38,40,42-trimothoxy* 37,39,41-tris [(3-nitrobenzyl)oxy]callx[6]arene (10) was synthesized according to procedure $B$ with 3-nitrobenzyl bromide $(128 \mathrm{mg})$. The crude solid was triturated with hot methanol to give pure 10: yield $130 \mathrm{mg}$ (93\%); mp 215-217 ${ }^{\circ} \mathrm{C}(\mathrm{MeOH}) ;{ }^{13} \mathrm{C} \mathrm{NMR} \mathrm{(62.5} \mathrm{MHz)} \mathrm{\&} \mathrm{(C3.}$ conformer) $154: 3,151,2,146.4,146,0,139.2,133.6,132.9$ (s, ArC), 132.1 $131.6,131.0,129.5,128.0,123.9(\mathrm{~d}, \mathrm{ArC}), 112.6(\mathrm{~s}, \mathrm{ArC}), 73.2\left(\mathrm{t}, \mathrm{OCH}_{2}\right)$ $60.3\left(\mathrm{q}, \mathrm{OCH}_{3}\right), 34.3,34.1\left(\mathrm{~s}, \mathrm{C}\left(\mathrm{CH}_{3}\right)_{3}\right), 31.6,31.2\left(\mathrm{q}, \mathrm{C}\left(\mathrm{CH}_{3}\right)_{3}\right)_{2}, 29.8$ (t, ArCH ${ }_{2}$ Ar); MS (FAB) m/e 1420.3 (M+ ${ }^{+}$, calod 1419.8). Anal. Calcd for $\mathrm{C}_{90} \mathrm{H}_{105} \mathrm{~N}_{3} \mathrm{O}_{2,}+0.5 \mathrm{H}_{2} \mathrm{O}: \mathrm{C}, 75.60 ; \mathrm{H}, 7.47 ; \mathrm{N}, 2.94$. Found: $\mathrm{C}, 75.69$ $\mathrm{H}, 7.61 ; \mathrm{N}, 2.92$. Karl Fischer titration; caled for $\mathrm{C}_{90} \mathrm{H}_{105} \mathrm{~N}_{3} \mathrm{O}_{12}-0.5 \mathrm{H}_{2} \mathrm{O}$ $0: 62$; found, 0.55

37,39,41-Trti!(3-cyanobenzyl)oxy\}-5,11,17,23,29,35-hexalds(1,1-dlinethylethyl)-36,40,42-trimethoxycallx[6]arene (11) was synthesized according to procedure B with 3-cyanobenzyl bromide (116 mg). The crudo solid was triturated with hot methanol to give pure 11: yield $128 \mathrm{mg}$ (96\%); mp 213-214 ${ }^{\circ} \mathrm{C}(\mathrm{MeOH}) ;{ }^{13} \mathrm{C} \mathrm{NMR}$ (62.5 MHz) o (C.30 conformer) $154.3,151.2,146.4,146.0,139.1,133.6,132.9,132.1,131.6$, $131.0,129.5,128.0,123.9,118.7,112.6(\mathrm{ArC}), 73.2\left(\mathrm{t}, \mathrm{OCH}_{2}\right), 60.3(\mathrm{q}$ $\left.\mathrm{OCH}_{3}\right), 34,3,34,0\left(\mathrm{~s}, \mathrm{C}\left(\mathrm{CH}_{3}\right)_{3}\right), 31,6,31.1\left(\mathrm{q}_{1} \mathrm{C}\left(\mathrm{CH}_{3}\right)_{3}\right), 29,8\left(t, \mathrm{ArCH}_{2-}\right.$ Ar); MS (FAB) $m / e 1360.7\left[(M+H)^{+}\right.$, calcd 1360.8]. Anal. Calcd for $\mathrm{C}_{93} \mathrm{H}_{105} \mathrm{~N}_{3} \mathrm{O}_{6}: \mathrm{C}, 82.08 ; \mathrm{H}, 7.78 ; \mathrm{N}, 3.09$. Found: $\mathrm{C}, 81.89 ; \mathrm{H}, 7.88$; N, 3.15.

37,39,41-Trta[(diethoxyphosphoryl)oxy\}-5,11,17,23,29,35-bexakds $(1,1$ dimathylethyl)-38,40,42-trimethoxycallx[6]arene (12). To a solution of $1(600 \mathrm{mg}, 0.59 \mathrm{mmol})$, diethoxyphosphoryl chloride $(1.66 \mathrm{~mL}, 11.5$ mmol), and tetrabutyl ammonium bromide ( $50 \mathrm{mg}$ ) in $\mathrm{CH}_{2} \mathrm{Cl}_{2}(40 \mathrm{~mL})$ was added a $\mathrm{NaOH}$ solution $(50 \mathrm{wt} \%, 20 \mathrm{~mL}$ ). The two-phase system was refluxed for $6 \mathrm{~h}$, whereupon were added water $(50 \mathrm{~mL})$ and $\mathrm{CH}_{2} \mathrm{Cl}_{2}$ $(100 \mathrm{~mL})$. The organic layer was separated, washed with water ( $50 \mathrm{~mL}$ ) $1 \mathrm{NHCl}(50 \mathrm{~mL})$, and brine $(25 \mathrm{~mL})$, and dried over $\mathrm{MgSO}_{4}$. The crude product was purffied by column chromatography (silica gel, EtOAc/ bexane 1:1) and subsequent recrystallization from $\mathrm{MeOH} / \mathrm{H}_{2} \mathrm{O}$ to give pure 12: yield $300 \mathrm{mg}(36 \%)$; $\mathrm{mp} 249-250^{\circ} \mathrm{C}\left(\mathrm{MeOH} / \mathrm{H}_{2} \mathrm{O}\right)$; $^{13} \mathrm{C} \mathrm{NMR}$ (62.5 MHz) \& ( $C_{3 v}$ conformer) $154.3,147.0,146.1,143.8,143.7,132.82$ $132.77,132.71(\mathrm{~s}, \mathrm{ArC}), 128.2,123.9(\mathrm{~d}, \mathrm{ArC}), 64.6,64.5\left(\mathrm{t}, J_{\mathrm{CP}}=25\right.$ $\left.\mathrm{Hz}_{1} \mathrm{OCH}_{2}\right), 60.0\left(\mathrm{q}, \mathrm{OCH}_{3}\right), 34.3,34.0\left(\mathrm{~s}, \mathrm{C}\left(\mathrm{CH}_{3}\right)_{3}\right), 31.6,31.1$ (q $\left.\mathrm{C}\left(\mathrm{CH}_{3}\right)_{3}\right), 30.4\left(\mathrm{t}, \mathrm{ArCH}_{2} \mathrm{Ar}\right)_{1}, 16.3,16.2\left(\mathrm{q}, J_{\mathrm{CP}}=25 \mathrm{~Hz}_{1} \mathrm{CH}_{2} \mathrm{CH}_{3}\right)$ MS (FAB) $m / e$ 1423.7 $\left[(\mathrm{M}+\mathrm{H})^{+}\right.$, calcd 1423.8]. Anal. Calcd for $\mathrm{C}_{31^{*}}$ $\mathrm{H}_{17} \mathrm{O}_{1} \mathrm{P}_{3} \cdot 0.3 \mathrm{H}_{2} \mathrm{O} ; \mathrm{C}, 68.08 ; \mathrm{H}, 8.29$. Found: $\mathrm{C}, 68.01 ; \mathrm{H}, 8.29$. Karl Fischer titration: caled for $\mathrm{C}_{81} \mathrm{H}_{117} \mathrm{O}_{15} \mathrm{P}_{3}+0.3 \mathrm{H}_{2} \mathrm{O}, 0.38$; found, 0.38 .

$5,11,17,23,29,35$-Hexalds (1,1-dimethylethyl)-38,40,42-trimethoxy37,39,41-tril[(2-maphthy]) methoxy] ealix[6arene (13) was synthesized according to procedure B with 2 (bromomethyl)naphthalene $(87 \mathrm{mg}$ $0.39 \mathrm{mmol}, 4$ equiv). The crude solid was triturated with hot EtOH to give pure 13; yield $108 \mathrm{mg}(77 \%) ; \mathrm{mp} 231-233^{\circ} \mathrm{C}$; ${ }^{13} \mathrm{C}$ NMR $(62.5$ $\mathrm{MHz}) \delta$ ( $C_{36}$ conformer) $154.5,151.8,145.9,145.8,135.2,133.9,133.4$, $133.2,133.1$ (s, ArC), 128.2, 128.1, 128.0, 127.7, 126.8, 126.1, 126.0 $125.9,123.7(\mathrm{~d}, \mathrm{ArC}), 74.7\left(\mathrm{t}, \mathrm{OCH}_{2}\right), 60.3\left(\mathrm{q}, \mathrm{OCH}_{3}\right), 34.2,34.0(8$ $\left.C\left(\mathrm{CH}_{3}\right)_{3}\right), 31.7,31.2\left(q_{1} \mathrm{C}\left(\mathrm{CH}_{3}\right)_{3}\right), 30.0\left(\mathrm{t}_{3} \mathrm{ArCH} \mathrm{Crr}_{2} \mathrm{Ar}\right) \mathrm{MS}(\mathrm{FAB}) \mathrm{m} / \mathrm{e}$ 1434.6 [M+ caled 1434.9]. Anal. Calad for $\mathrm{C}_{102} \mathrm{H}_{114} \mathrm{O}_{6} \cdot 0.3 \mathrm{H}_{2} \mathrm{O}: \mathrm{C}_{1}$ 84.99; H, 8.01. Found; $\mathrm{C}, 84.69 ; \mathrm{H}, 8.24$, Karl Fischer titration: caled for $\mathrm{C}_{102} \mathrm{H}_{114} \mathrm{O}_{6} \cdot 0.3 \mathrm{H}_{2} \mathrm{O}, 0.37$; found, 0.33 .

$5,11,17,23,29,35-$ Hexalds (1,1-dimethylethyl)-38,40,42-trimethoxy$37,39,41-\operatorname{tri}[$ (4-phenylbenzyl) oxy callix[6)arene (14) was synthesized according to procedure $B$ with 4.(chloromethyl) biphenyl ( $80 \mathrm{mg}, 0.392$ mmol, 4 equiv). The cride solid was triturated with hot EtOH to give pure 14: yield $132 \mathrm{mg}(89 \%) ; \mathrm{mp} 242-244^{\circ} \mathrm{C} ;{ }^{13} \mathrm{C} \mathrm{NMR}(62.5 \mathrm{MHz})$ $\delta\left(C_{3 v}\right.$ conformer) $154.5,151.7,145,9,145.8,141.1,140.8,136.8,133.9$ $133.2(\mathrm{~s}, \mathrm{ArC}), 128.7,128.5,128.0,127.3,127.2,127.1,123.6(\mathrm{~d}, \mathrm{ArC})$, $\left.74.3\left(\mathrm{t}, \mathrm{OCH}_{2}\right), 60.3(\mathrm{q}, \mathrm{OCH})_{3}\right), 34.3,34.0\left(\mathrm{~s}, \mathrm{C}\left(\mathrm{CH}_{3}\right)_{3}\right), 31.7,31.2(\mathrm{q}$, $\left.\mathrm{C}\left(\mathrm{CH}_{3}\right)_{3}\right), 29.9\left(\mathrm{t}, \mathrm{ArCH}{ }_{2} \mathrm{Ar}\right)$; MS (FAB) m/e 1513.1 [M+, calcd 1512.9] Anal. Calcd for $\mathrm{C}_{108} \mathrm{H}_{120} \mathrm{O}_{6}: \mathrm{C}, 85.67 ; \mathrm{H}, 7.99$. Found: $\mathrm{C}, 85.34 ; \mathrm{H}$, 8.25 .

37,39,41-Trd: $((N, N$-diethybumino $)$ carbonyl $)$ methoxy $-5,11,17,23,29$,35-hexalds(1,1-dimethylethyl)caldx6)arene-38,40,42-triol (15), In order to prepare the sodium complex a solution of $3(460 \mathrm{mg}, 0.34 \mathrm{mmol})$ in $\mathrm{CH}_{2} \mathrm{Cl}_{2}(50 \mathrm{~mL})$ was washed with brine $(2 \times 25 \mathrm{~mL})$ and dried over $\mathrm{MgSO}_{4}$. After removal of the solvent the residue was dissolved in dry $\mathrm{CHCl}_{3}(25 \mathrm{~mL})$. TMSI $(0.29 \mathrm{~mL}, 2.04 \mathrm{mmol})$ was added, and the mixture was refluxed for $8 \mathrm{~h}$, cooled, and subsequently quenched with $10 \% \mathrm{HCl}$ $(20 \mathrm{~mL}), \mathrm{CH}_{2} \mathrm{Cl}_{2}(100 \mathrm{~mL})$ was added, and the organiclayer was washed with $\mathrm{Na}_{2} \mathrm{~S}_{2} \mathrm{O}_{7}$ solution $(10 \mathrm{~mL})$ and water $(3 \times 25 \mathrm{~mL})$ and dried over $\mathrm{MgSO}_{4}$. The crude residue was triturated with $\mathrm{MeOH}$ to obtain pure 15: yield $370 \mathrm{mg}(83 \%)$; mp $218-220^{\circ} \mathrm{C}$ dec; ' $\mathrm{H}$ NMR $87.26,7.42$ (s, $0.4 \mathrm{H}), 7.1-6.9(\mathrm{~m}, 11.6 \mathrm{H}), 6.62(\mathrm{~s}, 1.2 \mathrm{H}), 4.6-3.1(\mathrm{~m}, 25.2 \mathrm{H}), 3.0-2.8$, 2.3-2.2(m, 1.2 H), 1.3-1.0 (m, 72 H), 0.8-0.6, 0.3-0.2(m, 1.9 H); MS (FAB) $\mathrm{m} / \mathrm{e}$ 1312.2 [(M+H)+, calcd 1312.9]. Anal. Calcd for $\mathrm{CH}_{4-}$ 
$\mathrm{H}_{177} \mathrm{~N}_{3} \mathrm{O}_{9}: \mathrm{C}, 76.85 ; \mathrm{H}, 8.98 ; \mathrm{N}, 3.20$. Found: $\mathrm{C}, 76.78 ; \mathrm{H}, 9.03 ; \mathrm{N}$, 3.31 .

37,39,41-Tris:((N,N-diethylamino) curbouyl)methoxy\}-5,11,17,23,29,35-hexakin (1,1-dimethylethyl)-38,40,42-triethoxycallix 6 aneme (16) was synthesized according to procedure $A$ by alkylation of 15 (150 mg, 0.11 mmol) with EtI (176 $\mu \mathrm{L}, 2.2 \mathrm{mmol}$ ) and $\mathrm{NaH}(50 \%$ in oil, $48 \mathrm{mg}$, mmol). The crude product was purified by column chromatography (silica gel) by first eluting with hexare and then with ethyl acetate. The compound was recrystallized from $\mathrm{MeOH} / \mathrm{H}_{2} \mathrm{O}$ : yield $89 \mathrm{mg}(58 \%)$; mp 248-249 ${ }^{\circ} \mathrm{C}\left(\mathrm{MeOH} / \mathrm{H}_{2} \mathrm{O}\right)$; ' $\mathrm{H}$ NMR $\left(400 \mathrm{MHz}, \mathrm{CD}_{2} \mathrm{Cl}_{2}\right) \delta\left(\mathrm{C}_{30}\right.$ conformer) 7.18, 6.57 (s, $6 \mathrm{H}, \mathrm{ArH}), 4.46\left(\mathrm{~s}, 6 \mathrm{H}, \mathrm{OCH}_{2} \mathrm{CO}\right), 4.36$ (d, $\left.J=14.8 \mathrm{~Hz}, 6 \mathrm{H}, \mathrm{ArCH}_{2 x} \mathrm{Ar}\right), 3.6-3.3\left(\mathrm{~m}, 18 \mathrm{H}, \mathrm{ArCH}_{\mathrm{maA}} \mathrm{N}\left(\mathrm{CH}_{2-}\right.\right.$ $\left.\left.\mathrm{CH}_{3}\right)_{2}\right), 3.0-2.9\left(\mathrm{br} \mathrm{m}, 6 \mathrm{H}, \mathrm{OCH}_{2} \mathrm{CH}_{3}\right), 1.30,0.72\left(8,27 \mathrm{H}, \mathrm{C}\left(\mathrm{CH}_{3}\right)_{3}\right)$, $1.2-1.0\left(\mathrm{~m}, 18 \mathrm{H}, \mathrm{N}\left(\mathrm{CH}_{2} \mathrm{CH}_{3}\right) 2\right), 0.5-0.4\left(\mathrm{br} \mathrm{m}, 9 \mathrm{H}, \mathrm{OCH}_{2} \mathrm{CH}_{3}\right) ;{ }^{3} \mathrm{C}$ NMR $(62.5 \mathrm{MHz}) \delta 167.6(\mathrm{~s}, \mathrm{C}-\mathrm{O}), 153.5,152.1,145.9,145.3,132.9$, 132.8 (s, ArC), 127.9, 123,8 (d, ArC), 72.8, 68.6 (t, OCH ${ }_{2} \mathrm{CO}, 0 \mathrm{OCH}_{2}-$ $\left.\mathrm{CH}_{3}\right), 41.8,40.1\left(\mathrm{t}, \mathrm{N}\left(\mathrm{CH}_{2} \mathrm{CH}_{3}\right)_{2}\right), 34.2,33.9\left(\mathrm{~s}, \mathrm{C}\left(\mathrm{CH}_{3}\right)_{3}\right), 31.6,31.2$ $\left(\mathrm{q}, \mathrm{C}\left(\mathrm{CH}_{3}\right)_{3}\right), 30.2\left(\mathrm{t}, \mathrm{ArCH} \mathrm{CHr}_{2}\right), 14.9,14.5\left(\mathrm{q}, \mathrm{N}\left(\mathrm{CH}_{2} \mathrm{CH}_{3}\right)_{2}\right), 12.1$ (q,

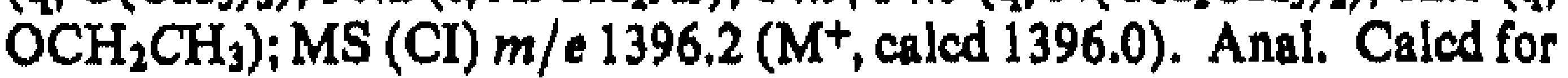
$\mathrm{C}_{20} \mathrm{H}_{129} \mathrm{~N}_{3} \mathrm{O}_{9}: \mathrm{C}, 77.38 ; \mathrm{H}, 9.31 ; \mathrm{N}, 3.00$. Found: $\mathrm{C}, 77.29 ; \mathrm{H}, 9.40$; $\mathrm{N}, 3.11$.

37,39,41-Trss ( $\left(N_{0} N\right.$-dethylamino $)$ carbonyl) metboxy $\}-5,11,17,23,29,-$ 35-hexakbs (1,1-dimethylethyl)-38,40,42-tripropoxycallixf6urene (17) was synthesized according to procedure $B$ by alkylation of $15(150 \mathrm{mg}, 0.11$ $\mathrm{mmol}$ ) with $\operatorname{Pr} \mathrm{Br}(63 \mu \mathrm{L}, 0.69 \mathrm{mmol})$ and $\mathrm{Cs}_{2} \mathrm{CO}_{3}(224 \mathrm{mg}, 0.69 \mathrm{mmol})$. An analytical sample was obtained by recrystallization from $\mathrm{MeOH}$ at $-30^{\circ} \mathrm{C}$ to give pure 17: yield $156 \mathrm{mg}(95 \%) ; \mathrm{mp} 249-252^{\circ} \mathrm{C}(\mathrm{MeOH})$; ${ }^{1} \mathrm{H}$ NMR 7.6-6.5 (m, 12 H, ArH), 4.6-3.2( $\mathrm{m}, 30 \mathrm{H}, \mathrm{ArCH}_{2} \mathrm{Ar}, \mathrm{N}\left(\mathrm{CH}_{2-}\right.$ $\left.\mathrm{CH}_{3}\right)_{3}, \mathrm{OCH}_{2} \mathrm{CO}$ ), 2.2-1.7(br m, 6 H, OCH $\left.\mathrm{CH}_{2} \mathrm{CH}_{3}\right), 1.4-0.7$ (m, 75 $\left.\mathrm{H}, \mathrm{C}\left(\mathrm{CH}_{3}\right)_{3}, \mathrm{~N}\left(\mathrm{CH}_{2} \mathrm{CH}_{3}\right)_{2}, \mathrm{OCH}_{2} \mathrm{CH}_{2} \mathrm{CH}_{3}\right), 0.4-0.0(\mathrm{br} \mathrm{m}, 6 \mathrm{H}$, $\left.\mathrm{OCH}_{2} \mathrm{CH}_{2} \mathrm{CH}_{3}\right),-0.1$ to $-0.2,-0.5$ to -0.7 (br m, $\left.6 \mathrm{H}, \mathrm{OCH}_{2} \mathrm{CH}_{2} \mathrm{CH}_{3}\right)$; MS (FAB) $m / e$ 1438.5 ( $\mathrm{M}^{+}$, caled 1438.0). Anal. Caled for $\mathrm{C}_{93^{*}}$ $\mathrm{H}_{135} \mathrm{~N}_{3} \mathrm{O}_{9}-\mathrm{H}_{2} \mathrm{O}: \mathrm{C}, 76.66 ; \mathrm{H}, 9.75 ; \mathrm{N}, 2.88$. Found: $\mathrm{C}, 76.89 ; \mathrm{H}, 9.69$; $\mathrm{N}$, 2.67. Karl Fischer titration; calcd for $\mathrm{C}_{93} \mathrm{H}_{135} \mathrm{~N}_{3} \mathrm{O}_{9} \cdot \mathrm{H}_{2} \mathrm{O}, 1.24$; found, 1.25 .

5,17,29-T-1s (1,1-timethylethyl)-37,39,41-trimethoxycallix (6) arenc-38, 40,42-triol (18). To a solution of $1(3.0 \mathrm{~g}, 3.0 \mathrm{mmol})$ in dry toluene (50 $\mathrm{mL}$ ) was added freshly sublimated $\mathrm{AlCl}_{3}(3.0 \mathrm{~g} .22 .5 \mathrm{mmol})$. The mixture was stirred vigorously for $10 \mathrm{~min}$, quenched with $1 \mathrm{~N} \mathrm{HCl}(50 \mathrm{~mL})$, and extracted with $\mathrm{CH}_{2} \mathrm{Cl}_{2}(2 \times 50 \mathrm{~mL})$. The organic layer was washed with $1 \mathrm{~N} \mathrm{HCl}(1 \times 50 \mathrm{~mL})$ and brine $(25 \mathrm{~mL})$ and dried over $\mathrm{MgSO}_{4}$. The crude solid was triturated with hot hexane to obtain pure 18: yield 2.03 g (81\%); mp 262-264 ${ }^{\circ} \mathrm{C}$ dec (hexane); 'H NMR (250 MHz) 87.00 (d, $J=7.5 \mathrm{~Hz}, 6 \mathrm{H}, \mathrm{ArH}), 6.92(\mathrm{~s}, 6 \mathrm{H}, \mathrm{ArH}), 6.88(\mathrm{~s}, 3 \mathrm{H}, \mathrm{OH}), 6.73(\mathrm{t}$, $J=7.5 \mathrm{~Hz}, 3 \mathrm{H}, \mathrm{ArH}), 3.91\left(\mathrm{~s}, 12 \mathrm{H}, \mathrm{ArCH}_{2} \mathrm{Ar}\right), 3.51\left(\mathrm{~s}, 9 \mathrm{H}, \mathrm{OCH}_{3}\right)$, $1.05\left(\mathrm{~s}, 27 \mathrm{H}, \mathrm{C}\left(\mathrm{CH}_{3}\right)_{3}\right){ }^{13} \mathrm{C} \mathrm{NMR}(62.5 \mathrm{MHz}) \delta 152.4,152.0,147.2$, $132.3,127.3$ (s, ArC), 128.8, 125.8, 120.0 (d, ArC), $61.4\left(\mathrm{q}, \mathrm{OCH}_{3}\right), 34.1$ $\left(\mathrm{s}, \mathrm{C}\left(\mathrm{CH}_{3}\right)_{3}\right), 31,3\left(\mathrm{q}, \mathrm{C}\left(\mathrm{CH}_{3}\right)_{3}\right), 31,0(\mathrm{t}, \mathrm{ArCH} 2 \mathrm{Ar}) ; \mathrm{MS}$ (FAB) $\mathrm{m} / \mathrm{e}$ $846.7\left(\mathrm{M}^{+}\right.$calcd 846.5$)$. Anal. Calcd for $\mathrm{C}_{37} \mathrm{H}_{66} \mathrm{O}_{6} 0.5 \mathrm{H}_{2} \mathrm{O}: \mathrm{C}, 79.97$; $\mathrm{H}, 7.89$. Found: $\mathrm{C}, 79.83 ; \mathrm{H}, 7.90$. Karl Fischer titration: calcd for $\mathrm{C}_{37} \mathrm{H}_{66} \mathrm{O}_{6} \cdot 0.5 \mathrm{H}_{2} \mathrm{O}, 1.05$; found, 1.11 .

5,17,29-Tris (1,1-dimethylethyl)-37,39,41-trimethoxy-38,40,42-trdir(3nitrobenzyl) oxy cally [6 arene (19) was synthesized according to procedure B by alkylation of 18 ( $75 \mathrm{mg}, 0.089 \mathrm{mmol})$ with 3-nitrobenzyl bromide (77 $\mathrm{mg}_{1} 0.36 \mathrm{mmol}$ ) and $\mathrm{Cs}_{2} \mathrm{CO}_{3}(174 \mathrm{mg}, 0.53 \mathrm{mmol}$ ). After workup the crude solid was recrystallized from MeOH: yield $89 \mathrm{mg}$ (80\%); $\mathrm{mp}$ 255-257 ${ }^{\circ} \mathrm{C}(\mathrm{MeOH}) ;{ }^{1} \mathrm{H}$ NMR (250 MHz) $88.33(\mathrm{~s}, 3 \mathrm{H}, \mathrm{PhH}), 8.16$, $7.64(\mathrm{~d}, J=7.8 \mathrm{~Hz}, 3 \mathrm{H}, \mathrm{PhH}$ ), 7.47 (dd, $J=8.0 \mathrm{~Hz}$ and $J=7.8 \mathrm{~Hz}$, $3 \mathrm{H}, \mathrm{PhH}), 7.14(\mathrm{~s}, 6 \mathrm{H}, \mathrm{ArH}), 6.79(\mathrm{~d}, J=7.5 \mathrm{~Hz}, 6 \mathrm{H}, \mathrm{ArH}), 6.64$ $(\mathrm{t}, J=7.5 \mathrm{~Hz}, 3 \mathrm{H}, \mathrm{ArH}), 4.71\left(\mathrm{~s}, 6 \mathrm{H}, \mathrm{OCH}_{2}\right), 3.93\left(\mathrm{~s}, 12 \mathrm{H}, \mathrm{ArCH} \mathrm{CHr}_{2}\right.$, $2.76\left(\mathrm{~s}, 9 \mathrm{H}, \mathrm{OCH}_{3}\right), 1.21\left(\mathrm{~s}, 27 \mathrm{H}, \mathrm{C}\left(\mathrm{CH}_{3}\right)_{3}\right) ;{ }^{13} \mathrm{C} \mathrm{NMR}(62.5 \mathrm{MHz})$ 8 154.1, 153.7, 148.3,146.2 139.8, 134.7 (s, ArC), 133.6 (d, ArC), 133.2 (s, ArC) $129.4,128.0,127.0,124.0,122.7,122.5(\mathrm{~d}, \mathrm{ArC}), 72.8(\mathrm{t}$, $\left.\mathrm{OCH}_{2}\right), 59.8\left(\mathrm{q}, \mathrm{OCH}_{3}\right), 34.2\left(\mathrm{~s}, \mathrm{C}\left(\mathrm{CH}_{3}\right)_{3}\right), 31.4\left(\mathrm{q}, \mathrm{C}\left(\mathrm{CH}_{3}\right)_{3}\right), 30.7(\mathrm{t}$, $\mathrm{ArCH}_{2} \mathrm{Ar}$ ); $\mathrm{MS}$ (FAB) $m / e$ 1250.1 [(M-H) - calod 1250.6]. Anal. Calcd for $\mathrm{C}_{78} \mathrm{H}_{61} \mathrm{~N}_{3} \mathrm{O}_{12}: \mathrm{C}_{1} 74.8 ; \mathrm{H}_{2} 6.52 ; \mathrm{N}, 3.35$. Found: $\mathrm{C}_{7} 74.46 ; \mathrm{H}, 6.62$; $\mathrm{N}, 3.33$.

Abbreviations. $C_{30}$ symmetry class characterized by the symmetry elements $\left(E, C_{3} 3 \sigma_{v}\right) ; C_{1}$, symmetry class characterized by the symmetry elements $\left(E, \sigma_{n}\right)$; DQF-COSY, double quantum filtered correlation spectroscopy; TQF-COSY, triple quantum filtered correlation spectroscopy: HMQC, heteronuclear multiple quantum correlation; HMBC, heteronuclear multiple bond correlation; NOESY, nuclear Overhauser spectroscopy; TOCSY, total correlation spectroscopy; TPPI, timeproportional phase incrementation.

NMR Measurements. NMR measurements were either performed at 250,400 , or $600 \mathrm{MHz}$, on Bruker AC250, Varian Unity $400 \mathrm{WB}$, or
Bruker AMX600 spectrometern, respectively. Me,Si was used as internal standard, unless stated otherwice. NOESY, ${ }^{33,37}$ ROESY, ${ }^{38}$ TOCSY (MLEV17), ${ }^{39}$ DQF-COSY, ${ }^{\circ}$ TQF-COSY, 41 HMQC, and HMBC ${ }^{43}$ were performod, using standard .Bruker and Varian pulse programs. All TOCSY (MLEV17) experiments were performed with mixing times of $30 \mathrm{~ms}$. The mixing times of the NOESY experiments ranged from 100 to $700 \mathrm{~ms}$. The mixing time of the ROESY experiments consisted of a spin lock pulse of $2-\mathrm{kHz}$ field strength with a duration of $300 \mathrm{~ms}$. In all AMX600 2D NMR experiments TPPI was usod for aignal accumulation in the t, dimension. ${ }^{43}$ All $2 \mathrm{D}$ experiments performod on the Unity $400 \mathrm{WB}$ were collected using 2D hypercomplex data.4 Data were Fourier transformed in the phase-sensitive mode after weighting with shifted square sine-bells of shifted Gaussian functions. NMR data were processed either by the atandard Varian VnmrS/V $n$ mrX software packages installod on the Unity 400WB spectrometer host computer (SUN Sparc 10) or by the NMRi package installed on a SUN4 computer. Thermodynamic parameters $\left(\Delta G^{\circ}\right)$ were derived from equilibrium constants, which could be derived from signal integrals in 1D 'H NMR spectra recorded at 400 MHz. $\Delta G^{\prime}$ values were calculatod from interconversion rate constants, which were determined by integration of exchange peaks in EXSY/ NOESY experiments.

Molectuar Modellug. All calculations were done on a Silicon Graphics Iris 4D/240 GTX using the programs QUANTA 3.3/CHARMm 22 package.45 The parameter set of the programs was used. Partial charges were calculated with Quanta charge templates. The resulting net charge was smoothed out over all atoms to obtain a total charge of zero for the molecule. The nonbonded interactions were calculatod with a cutoff of $14 \mathrm{~A}$ and a dielectric constant of 1 . The energy minimizations were performed with the adopted-basis Nowton-Raphson method (ABNR) until the energy gradient wes lower than $0.01 \mathrm{kcal}^{\mathrm{mol}-1} \mathrm{~A}^{-1}$. The molecules were constructed in Quanta ChemNote and energy minimizod with the steepest descent method to remove the worst contacts. Subsequently the NOE dlstanco constraints as obtained from the NMR experiments were applied and tho structures were further minimized using the ABNR method. In order to obtain a representative low-energy conformation of the substituents, the following procedure was used: The molecule was heated to $600 \mathrm{~K}$ in 7 ps and equilibrated at $600 \mathrm{~K}$ for 7 $\mathrm{ps}$, and subsoquently $40 \mathrm{ps}$ of molecular dynamics calculations were run. During the whole procedure the NOE constraints were applied to restrain the calix[6]arene to the given geometry and to let only the substituents move freely. Then the structure with the lowest energy during the simulation was picked up and energy minimized.

Acknowledgment. Elemental analyses were performed by Mrs. A. Montanaro-Christenhusz, and mass spectra were recorded by Mr. T. W. Stevens. Mrs. H. Visser and Mr. E. van Velzen are acknowledged for performing a part of the NMR experiments and keeping the. Varian Unity $400 \mathrm{WB}$ in perfect condition. Part of the NMR experiments were carried out at the SON hfNMR facility (Nijmegen, The Netherlands). The authors are indebted to its staff for their expert assistance. The research described in this paper was partly supported by The Netherlands Foundation for Chemical Research (SON) with financial aid from The Netherlands Organization for Scientific Research (NWO), the Dirección General de Investigación Cientifica y TÉnica (DGICYT Grant PB 90-0212), the Italian M.U.R.S.T., and the EEC Twinning Project $\mathrm{SCl}^{*}=03259$, P.M.N, gratefully acknowledges a NATO fellowship for a research visit to the University of Parma,

(37) Jeener, J.; Meier, B. H.; Bachmann, P.; Ernst, R. R. J. Chem, Phys. 979, $71,4546-4553$.

(38) Bothner-By, A. A.; Stephens, R. L.; Lo, L.; Warren, C. D.; Jaanloz, R. W. J. Am. Chem. Soc. 1994, 106,811-813,

(39) Bax, A, Davis, D. J. Magn. Reson. 1985, 65, 355-366.

(40) Rance, M.; Sorensen, O. W.; Bodenbausen, O.; Wagner, G,; Ernst, R. R.; Wathrich, K. Blochem, Blophys. Res, Commun. 1983, II7, 479-485. (41) Piantini, U.; Sorensen, O. W, Ernst, R. R. J. Am. Chem. Soc, 1982, $104,6800-6801$.

(42) Summers, M. F,; Marzilli, L. G.; Bax, A. J. Am, Chem, Soc, 1986, $108,4285-4294$.

(43) Marion, D.; Wütrich, K. Blochem. Blophys. Res. Commun. 1983, $113,967-974$.

(44) States, D. J.; Haberkorn, R. A.; Ruben, D. J. J. Magn. Reson. 1982, 48, 286-292.

(45) Quanta 3.3: Molecular Simulations Inc,; CHARMm22: Brooks, B. R.; Bruccoleri, R. E.; Olafson, B. D.; States, D. F.; Swaminathan, S.; Käplus, M. J. Comput. Chem. 1983, 4, 187-217. 